\title{
COMMENTS
}

\section{PROTECTING "DONOR INTENT" \\ IN CHARITABLE FOUNDATIONS: WAYWARD TRUSTEESHIP AND THE BARNES FOUNDATION}

\author{
CHRIS ABBINANTE†
}

\begin{abstract}
"Well, if George could not get the fish, the fish would not get the cake. George would eat it. He liked cake too. He would find another way to get a fish."
\end{abstract}

\section{INTRODUCTION}

Philanthropy- "The effort or inclination to increase the wellbeing of humankind, as by charitable aid or donations." ${ }^{2}$ This Comment addresses one of the many forms of philanthropy-the charitable foundation-also known as the charitable trust. Although different types of charitable foundations exist, this Comment uses the term generally to designate institutions established through private wealth, devoted to public purposes and intended to be perpetual in nature. ${ }^{3}$

The twentieth century has seen the rise of the foundation as a crucial and widely used vehicle for philanthropic activity. ${ }^{4}$ The

† B.B.A. 1994, University of Notre Dame; J.D. Candidate 1997, University of Pennsylvania. I would like to thank the members of the Law Review who provided suggestions and carefully edited my Comment. Thanks also to Russell P. Kanjorski for his insightful ideas and to Professors Bruce H. Mann and William C. Tyson for their reviews of and contributions toward this Comment. Finally, special thanks to my family, especially my wife, Martha, who allowed me to keep my research materials scattered throughout our living room for months before threatening to throw them and me out.

1 Margret \& H.A. Rey, Curious George Flies a Kite, in THE COMPLETE ADVENTURES OF CURIOUS GEORGE 201, 245 (1995).

2 AMERICAN HERTAGE DiCTIONARY OF THE ENGLiSH LANGUAGE 1359 (3d ed. 1992).

${ }^{3}$ See BLACK'S LAW DICTIONARY 234 (6th ed. 1990) (defining "charitable foundation"); EDITH L. FISCH ET AL., CHARITIES AND CHARITABLE FOUNDATIONS $§ 36$, at 35-36 (1974) (same). For a more detailed definition of the charitable trust, see infra Part II.A.

${ }^{4}$ See Teresa Odendahl, Independent Foundations and Wealthy Donors: An Overview, in AMERICA'S WEALTHY AND THE FUTURE OF FOUNDATIONS 1,1 (Teresa Odendahl ed., 
growth of charitable trusts coincided with the Industrial Revolution. Industrialization allowed entrepreneurs and opportunists to develop massive personal fortunes. Capitalists such as Henry Ford, John D. Rockefeller and Andrew Carnegie amassed incredible wealth in the late nineteenth and early twentieth centuries. ${ }^{5}$ These men and others of similar means recognized the value of charitable trusts as instruments that allowed them to donate funds for the public welfare while maintaining control over the use of those funds. ${ }^{6}$ Indeed, these multimillionaires and billionaires envisioned the charitable trust as a vehicle through which they could implement their personal charitable philosophies and affect society in the ways they deemed most beneficial. ${ }^{7}$ Beyond the commonly known Ford Foundation and Carnegie Corporation, there are thousands of smaller foundations that either donate funds to worthy causes or operate benevolent institutions themselves. ${ }^{8}$ One foundation that uses its endowment to support its own benevolent program is the Barnes Foundation. The Barnes Foundation is a charitable trust that was created by Dr. Albert Barnes, a chemist who made a fortune in pharmaceuticals in the late nineteenth and early twentieth centuries." Dr. Barnes established the Foundation for "the advancement of education and the appreciation of the fine arts." $\mathrm{He}$ donated his priceless collection of Impressionist art to the Foundation and built a facility in suburban Philadelphia

1987) [hereinafter AMERICA'S WEALTHY] (stating that early twentieth century entrepreneurs used foundations to promote their personal visions of society).

See id.

${ }^{6}$ See generally FISCH ET AL., supra note $3, \S 42$, at $41-42$ (identifying the motivating factors behind the creation of charitable trusts).

7 See Francie Ostrower, The Role of Advisors to the Wealthy, in AMERICA's WEALTHY, supra note 4, at 247, 257 ("[C]lients who choose a foundation are those who want to have an influence over how their wealth will be applied.").

${ }^{8}$ See JeSSE DUKEMINIER \& STANLEY M. JOHANSON, WILls, TRUSTS, AND ESTATES 617 (4th ed. 1990) (noting that, as of 1986, over 24,000 independent foundations in the United States maintained more than $\$ 90$ billion in assets and distributed about $\$ 6$ billion annually to nonprofit causes); Stephan Salisbury, Private Mone;, Public Potver, PHILA. INQUIRER, Oct. 13, 1996, at Al, A26 (stating that, according to the Foundation Center, as of 1995 there were nearly 39,000 foundations with assets totalling almost $\$ 196$ billion).

${ }^{9}$ See Howard GReenfeld, The Devil and DR. BARNes 9-29 (1987) (discussing Dr. Barnes's education in medicine, his career in chemistry, and the fortune he made through the sale of the drug, Argyrol, which Barnes invented along with fellow scientist Hermann Hille).

${ }^{10}$ Barnes Indenture and Agreement, at Introduction (Dec. 6, 1922) (contract establishing the Foundation, on file with the University of Pennsylvania Law Review) [hereinafter Barnes Indenture]. 
to house the collection." Barnes also gave millions of dollars for the maintenance of the collection and the creation of an educational program centered around the art. ${ }^{12}$

Unfortunately, the trustees who control the Barnes Foundation, as well as the trustees of many other major charitable foundations, are presently involved in a struggle between their duty to fulfill the intentions of their donors and their desire to dedicate their foundations' assets to other pursuits. ${ }^{\text {13 }}$ Donors' wishes cannot always be accommodated due to economic changes, modifications of the tax $\operatorname{code}^{14}$ or other statutory guidelines affecting foundations, evolving societal needs, or a host of other unforeseeable circumstances. ${ }^{15}$ Under certain circumstances the law allows the trustees of charitable foundations to deviate from the express instructions of donors. ${ }^{16}$ While there are instances in which trustees cannot follow donors' intentions if their foundations are to survive or remain viable, ${ }^{17}$ there are also many cases where donors' wishes are disregarded without proper

$"$ See Robert Hughes, Opening the Barmes Doors, TIME, May 10, 1993, at 61, 62 (discussing Barnes's construction of the Foundation's Merion, Pennsylvania facility from 900 tons of French limestone).

12 See id. (noting that the Foundation had an initial endowment of $\$ 6$ million and discussing Barnes's educational ambitions); see also GREENFELD, supra note 9, at 73-123 (discussing in great detail Barnes's intentions for the Foundation).

${ }^{13}$ See Lawrence Osborne, Are a Donor's Wishes Sacred?, NAT'L L.J., July 3, 1995, at A1 (discussing the controversy surrounding the Barnes Foundation-in particular, the question of whether the trustees deviated from Dr. Barnes's instructions); see also Brigid McMenamin, Donor Beware, FoRBES, Feb. 13, 1995, at 172, 172 (noting that trustees who control foundations often disregard the intentions of the founders, including such major American philanthropists as Henry Ford and Andrew Carnegie).

${ }^{14}$ See FISCH ET AL., supra note $3, \S 44$, at $48-49$ (discussing the implications of the Tax Reform Act of 1969 on charitable foundations).

${ }^{15}$ See, e.g., Trammell v. Elliott, 199 S.E.2d 194, 197-99 (Ga. 1973) (discussing the use of illegal racial classifications in the establishment of an educational scholarship fund). The Trammell court found that the trust could be modified to exclude the illegal classification as a criterion for receiving the charitable grant. See id. at 199. In In re Estate of Tomlinson, 359 N.E.2d 109, 110-13 (Ill. 1976), the court held that money bequeathed to the Cancer Research Fund, a nonexistent entity, could be given to the American Cancer Society, which sponsors cancer research.

${ }^{16}$ See FISCH ET AL., supra note $3, \$ \$ 561-89$, at $413-69$ (discussing the cy pres doctrine); see also Cy Pres and Deviation: Current Trends in Application, 8 REAL PROP. PROB. \& TR. J. 391, 391-404 (1973) [hereinafter Cy Pres and Deviation] (discussing the legal doctrines that allow charitable foundation trustees to deviate from the express or implied mandates of the trust under specific conditions). For further discussion of these trust law principles, see infra Part II.B-C.

${ }^{17}$ See Elias Clark et al., CASES AND Materials ON Gratuitous TRANSFERS 566 ( $3 \mathrm{~d}$ ed. 1985) (listing the circumstances, including impossibility, in which courts will allow deviations from donors' intentions). For discussion of the guidelines for appropriate deviations from donor intent, see infra Parts II.B-C. 
cause. ${ }^{18}$ The struggle today is to identify those cases where society and the legal system should not permit deviations from donors' wishes. The importance of this struggle is simple-society should ensure that donors' intentions are followed in order to encourage continued philanthropic activity by the wealthy. Charitable foundations have proven to be a valuable source of funding for research and education in the sciences, especially in the fields of medicine and health care. ${ }^{19}$ These institutions also provide support for the impoverished, the arts, religious institutions and community welfare. ${ }^{20}$ If potential donors decide not to fund foundations because the law fails to protect their intentions, valuable resources will be lost. ${ }^{21}$ Given donors' desire for control over their charitable contributions, ${ }^{22}$ it is possible that donors who lose faith in the foundation as a medium for giving might forego a large part of their publicly targeted philanthropic activities. ${ }^{23}$

${ }^{18}$ See, e.g., In re Estate of Buck, No. 23259 (Cal. Super. Ct. 1986), reprinted in 21 U.S.F. L. REV. 691 (1987) (rejecting an attempt by trustees to deviate from the express intent of the donor); McMenamin, supra note 13, at 174 (citing a case in which a trustee ignored the wishes of the donor in order to generate greater trustee fees); Martin Morse Wooster, Advice to Donors: Don't Die, WALL ST. J., Jan. 27, 1995, at A10 (noting the improprieties involved in the administration of the Ford, Carnegie and Rockefeller foundations). For more detailed discussion of trustee disregard for donor intent, see infra Part III.

${ }_{19}$ See FISCH ET AL., supra note $3, \S \S 296-307,322-23$, at $259-79$ (discussing the contributions made by charitable trusts to education and research); Teresa Odendahl, Foundations and the Nonprofit Sector, in AMERICA's WEALTHY, supra note 4, at 27, 35-39 (noting the dollar value of funds given to research and medicine).

Fair consideration of the merits of charitable trusts demands that this Comment recognize not only the benefits society gains from charitable trusts, but also the benefits these instruments provide for donors. Charitable trusts are a type of bargain between the public and the philanthropist. In return for donating her wealth for the betterment of the public welfare, the creator of a foundation is afforded preferred tax status as to her donated funds, and is allowed to dictate the charitable use of those funds into perpetuity. For further discussion of the benefits accruing to the donor of a charitable trust, see infra Part II.A.

20 See FISCH ET AL., supra note 3, §§ 272-83, 333-36, at 243-58, 281-88; Odendahl, supra note 19, at 35-39; see also Ralph Cipriano et al., Huge Grants to Boost Park and Library, PHILA. INQUIRER, Oct. 23, 1996, at Al (detailing the William Penn Foundation's $\$ 44$ million grant to Philadelphia's libraries and parks).

${ }^{21}$ See generally F. EMERSON ANDREWS, PHILANTHROPIC FOUNDATIONS 19 (1956) (calling foundation funds the "venture capital of philanthropy" providing resources relatively free from governmental control or interference to organizations that would otherwise be neglected and underfunded); DUKEMINIER \& JOHANSON, supra note 8, at 1 (noting that charitable foundations provide over $\$ 6$ billion annually in grants).

${ }_{22}$ See Teresa Odendahl, Wealthy Donors and Their Charitable Attitudes, in AMERICA's WEALTHY, supra note 4, at 223, 230.

${ }^{23}$ See Rob Atkinson, Reforming Cy Pres Reform, 44 Hastings L.J. 1111, 1121 (1993) (arguing that "disregarding donor intent will have an adverse effect on charitable giv- 
This Comment examines the problem of donative intent using the Barnes case as a touchstone. Part I discusses the history of the Barnes Foundation, from the purposes behind the Foundation's establishment and the wishes of its creator, to the dilemma that the Foundation now faces. This Part argues that the trustees of the Foundation violated their duties by neglecting the wishes of the late Dr. Barnes. In Part II, this Comment outlines the legal doctrines and precedents that control the administration of charitable trusts and deviations from donor intent. Part III details some other present-day situations where donor intent is regularly and wrongfully disregarded by the trustees of charitable foundations. These examples are included for comparison with the Barnes case, noting the legal and circumstantial differences, but focusing on the underlying similarities-specifically, the disregard for the wishes of the donor. In Part IV, this Comment examines the reasons why society should value donor intent and argues that the trustees of charitable foundations should be held to a higher level of accountability in upholding the intentions of donors. Finally, Part V contains recommendations on how philanthropists and the law can better preserve and protect donor intent.

\section{The Barnes Foundation: PASt AND Present Controversies}

\section{A. Albert Barmes and the Establishment of His Foundation}

Dr. Albert Barnes (1872-1951) was a Philadelphian and a graduate of the University of Pennsylvania Medical School. Barnes and German scientist, Hermann Hille, developed the pharmaceutical product Argyrol. ${ }^{24}$ Through the sale of Argyrol, Barnes quickly became a wealthy man. ${ }^{25}$ With his financial status secure, Barnes devoted most of his time to his passion-art. ${ }^{26}$ Because Barnes believed that he was not much of an artist, he collected the works of others. Barnes amassed a collection of Impressionist art that is enormous in

ing ${ }_{24}$.

See THE BaRnes Foundation: A Vision SHAREd (1996) [hereinafter A Vision SHARED]. Argyrol is a silver nitrate compound that was marketed by Barnes as an antiseptic for the treatment of infections. See GREENFELD, supra note 9, at 16-17 (1987).

${ }_{23}^{25}$ See GREENFELD, supra note 9, at 15-29 (discussing Barnes's tumultuous but highly successful entrepreneurial business).

${ }^{26}$ See Martin M. WOOSTER, THE Great Philanthropists \& THE Problem of "DONOR INTENT" 43 (1994) (noting that by 1910 Barnes was able to forego his chemistry career and pursue other passions such as art and philanthropy); see also A VISION SHARED, supra note 24 (discussing Barnes's interest in art, philosophy and psychology). 
volume and impressive in quality. ${ }^{27}$ Although his collection is now considered priceless, Barnes bought most of his paintings before they were valued by the art world. ${ }^{28}$

As his collection grew, so did Barnes's contempt for his peers in the art world and the upper class. ${ }^{20}$ Barnes felt slighted by the gentry of Philadelphia, and in response he disassociated himself from his contemporaries. ${ }^{30} \mathrm{He}$ expressed his bitterness by writing insulting letters and engaging in personal feuds with those he deemed detractors or enemies. ${ }^{31}$ Barnes's ultimate act of disassociation was his response to those who sought to view his collection. ${ }^{32}$

\section{The Foundation's Origin}

In 1922, Barnes created his Foundation. ${ }^{33}$ The Foundation was established to house Barnes's collection, ${ }^{34}$ but contrary to what would seem obvious, the Foundation's primary purpose was not to serve as a public museum. ${ }^{35}$ In fact, Barnes intentionally placed strict limita-

${ }^{27}$ See Hughes, supra note 11 , at 62 (noting that the Foundation began with over 700 paintings including 69 Cézannes, 60 Matisses, 44 Picassos and 180 Renoirs); see also Paul Richard, To Sell or Not to Sell: Philadelphia's Barnes Battle, WASH. POST, Apr. 28, 1991 , at G1 (stating that the Barnes collection is among the most valuable in America); WOOSTER, supra note 26, at 44 (noting that besides its extensive Impressionist collection, the Foundation also owned ancient African and Chinese art).

${ }_{28}$ See GREENFELD, supra note 9, at 89-102 (detailing the harsh reactions that Barnes's collection initially received from American art critics); see also Hughes, supra note 11 , at 63 (noting that in the early twentieth century modern art was looked upon with great disdain).

${ }_{29}$ See GREENFELD, supra note 9, at 89-102 (discussing Barnes's reaction to the negative responses that were voiced at the early exhibitions of his collection). The immense initial criticism Barnes received from American audiences left him bitter. See id. at 96 ("He had been hurt and stunned by the ignorance and insensitivity of the men and women who called themselves art critics, and he never forgave them.").

${ }^{\text {so }}$ See id. at $118-35$ (discussing Barnes's failed attempts to establish relationships with mainstream institutions and the resulting effects such failures had on Barnes's uncompromisingly rigid policy of restricted access to his Foundation).

${ }^{91}$ Included in this category were "journalists, art critics, dealers, other collectors, and other millionaires, representatives of the world of conservative academia[,] . . all those who had offended him in the past." Id. at 129.

${ }^{32}$ See id. (noting that Barnes refused to admit anyone on his blacklist and uncompromisingly restricted the admission of all members of high society and the art world).

See id. at 73.

${ }^{94}$ See Barnes Indenture, supra note 10, at Introduction ("Whereas, Donor is the owner of a valuable collection of works of art... which it is intended shall become the property of Donee and shall be placed in the gallery to be erected ....").

See Osborne, supra note 13, at A24 (noting that the "stunning collection was destined to be not a public museum but a school of art education of [Barnes's] devising"). 
tions on public access to the collection. ${ }^{36}$ Barnes envisioned the Foundation as an educational institution, established for instruction in his own philosophy of art. ${ }^{97}$ Barnes's theories about art education reflected the views of philosopher John Dewey, Barnes's friend and mentor. ${ }^{38}$ Dewey implemented these ideas as the Foundation's first director of art education. ${ }^{39}$

The Indenture ${ }^{40}$ that Barnes created to govern the Foundation detailed the proper function of the Foundation and contained many restrictions upon the use and administration of the collection. ${ }^{41}$ In addition to the aforementioned guidelines which restricted public ac-

${ }^{96}$ The Foundation's Indenture, last amended during Barnes's lifetime in 1946, allowed the general public to visit the collection only on Saturdays from September through June, and never in July and August. See Barnes Indenture, supra note 10, art. IX, I 30 (as amended Apr. 30, 1946). By 1995, the Foundation was open to the public three-and-a-half days per week. See In re Barnes Found., No. 3231 Phila. 1995, $1996 \mathrm{~Pa}$. Super. LEXIS 3155, at *4 n.3 \& *6-7 (Pa. Super. Ct. Sept. 12, 1996) (noting prior court orders which had opened the Foundation for two-and-a-half days per week and ordering another amendment to the Indenture which would provide for an additional day of public access).

${ }_{37}$ The Indenture states:

Donor makes these provisions and stipulations for the reason that said art gallery is founded as an educational experiment under the principles of modern psychology as applied to education, and it is Donor's desire during his lifetime... to perfect the plan so that it shall be operative for the spread of the principles of democracy and education after the death of the Donor ....

Barnes Indenture, supra note 10, art. IX, I 29. Barnes reiterated his instructions throughout the Indenture. "This means specifically that The Barnes Foundation is to be maintained perpetually for education in the appreciation of the fine arts and not as a school for instruction in painting, drawing, sculpturing ...." Id. I 34 (as amended Apr. 30, 1946).

${ }^{33}$ See Hughes, supra note 11, at 61 ('[Barnes's] intellectual mentor was the educator John Dewey, whose book Democracy and Education formed his ideas about education for 'the masses' through art."). Consistent with his desire to educate "the masses" and to disassociate himself from the upper class, Barnes intended for the Foundation to become an educational facility which would primarily benefit the "plain people... men and women who gain their livelihood by daily toil in shops, factories." Barnes Indenture, supra note 10, art IX, I 30 (as amended Apr. 30, 1946); see also Hughes, supra note 11, at 63 (describing Barnes's sympathy for the working class).

See A VISION SHARED, supra note 24.

40 A trust indenture is " $[\mathrm{t}]$ he document which contains the terms and conditions which govern the conduct of the trustee and the rights of the beneficiaries" of a trust. BLACK'S LAW DICTIONARY, supra note 3, at 1515.

${ }^{41}$ See, e.g., Barnes Indenture, supra note 10, art IX, I 13 ("All the paintings shall remain in exactly the places they are at the time of the death of Donor...."); Id. I 33 (" $[A] \mathrm{t}$ no time after the death of said Donor, shall there be held in any building.... any society functions commonly designated receptions, ... dinners, banquets, ... whether such functions be private or public."). 
cess to the collection, ${ }^{42}$ the Indenture outlined a severely limited investment policy for the Foundation's endowment. ${ }^{43}$ The Indenture strictly forbade charging entrance fees to the collection, ${ }^{44}$ the construction of new buildings on the Foundation's premises, and the loan or sale of any of the paintings under any circumstances short of physical deterioration. ${ }^{45}$ In an amendment to the Indenture, Barnes mandated that Articles I, II, IV, V and IX were "unamendable and shall never be amended in any manner whatsoever." These restrictions highlight the rigid and peculiar nature of Dr. Barnes's persona and his philanthropic ideology. The question of whether the trustees have the duty to adhere to these extreme guidelines is the cause of the controversies that have long cast a shadow over the Foundation's existence.

\section{The Foundation's History}

After Barnes's death in 1951, he left control of the Foundation to his wife, Laura. ${ }^{47}$ Following her death in 1966, control of the Foundation passed, in accordance with Barnes's wishes, to trustees appointed by Lincoln University, a small, African-American institution in Lincoln University, Pennsylvania. ${ }^{48}$ In 1961, the Foundation agreed to open its doors to the public twice a week due to a court order and the threat of revocation of its tax-exempt status, ${ }^{49}$ and three times a week following Laura Barnes's death. ${ }^{50}$

42 See id. 130.

43 See id. 127 (mandating that the Foundation's funds be invested only in lowyielding government securities).

${ }^{44}$ See id. 130 . The Court of Common Pleas amended the Indenture allowing the trustees to charge five dollars for admission to the Foundation. See In re Barnes Found., No. 3231 Phila. 1995, 1996 Pa. Super. LEXIS 3155, at *6-7 (Pa. Super. Ct. Sept. 12, 1996) (affirming the decision of the Court of Common Pleas).

45 See Barnes Indenture, supra note 10, art. IX, II 9-10.

${ }^{46} I d$. at art. X. Article IX, paragraph 5 says in part: "Donee expressly convenants and agrees that in consideration of the making of this agreement... Donee will take and hold the property so comprehended and covered in conformity with the following express convenants and agreements [i.e., the rest of the Indenture] and will strictly and faithfully observe and perform the same" Id. at art. IX, I 5 (emphasis added).

${ }_{77}$ See Hughes, supra note 11 , at 63.

${ }^{48}$ See id.

49 See GREENFELD, supra note 9, at 289. The Pennsylvania Supreme Court noted that "if the gallery was open to only a selected, restricted few, it was not a public institution; and that if it was not a public institution, it was not entitled to tax exemption." $I d$. at 288-89. For further discussion on the tax exemptions afforded charitable foundations, see infra Part II.A.

${ }^{30}$ See GREENFELD, supra note 9, at 289. 
Aside from the change in public access and a few minor alterations, the Foundation was administered according to Barnes's wishes throughout the 1960s and 1970s. Adherence to Barnes's intentions was due in large part to the tight-fisted control held by the last trustees Barnes had personally appointed, particularly Violette deMazia." Upon Mrs. deMazia's death in 1988, Lincoln University gained the sole right to appoint the Foundation's trustees. ${ }^{52}$ By the appointment of Lincoln's trustees, Richard Glanton, the University's general counsel and a lawyer from Philadelphia, became the Foundation's president, a title he continues to hold. ${ }^{53}$

\section{B. The Foundation in the 1990s: A Time of Conflict}

By the late 1980s the collection had little professional or private support. "It had no loyal audience, no generous trustees, no circle of scholars and museum professionals to give it support., ${ }^{, 54}$ Glanton and the other trustees argued that the administrative and investment restrictions $^{55}$ that Barnes had placed on the Foundation were hindering the facility's maintenance and quality. ${ }^{56}$ The trustees proposed the sale of some of the Foundation's "lesser" paintings to raise cash," even though the Indenture specifically prohibited the sale of any item in the collection. ${ }^{58}$ Once news of the proposed deaccessioning reached the public, the trustees were harshly criticized by the New York Times, the Philadelphia Inquirer, art dealers, the Smithsonian and members of the Barnes advisory committee. This negative sentiment ultimately caused the trustees to rescind their proposal..$^{59}$

Still determined to raise the funds they deemed necessary to sup-

5l See Hughes, supra note 11, at 63; Osborne, supra note 13, at A24.

52 See Osborne, supra note 13, at A24.

ss See id.; Hughes, supra note 11 , at 64 .

${ }^{34}$ Hughes, supra note 11 , at 63.

35 See Richard, supra note 27, at G4. For a description of the investment restrictions, see Barnes Indenture, supra note 10, art. IX, I 27.

${ }^{56}$ See Hughes, supra note 11 , at 63 . It is unrefuted that Barnes's investment policies hindered the upkeep of the Foundation. Because of Barnes's insistence on utilizing nonappreciating securities, some of which earned less than three percent annually, the Foundation's endowment was unable to keep up with inflation. See id.; see also Richard, supra note 27 , at G4.

${ }^{57}$ See Hughes, supra note 11 , at 64 (noting that "Glanton proposed selling 'redundant' works to pay for the repairs he considered necessary, the cost of which was estimated at $\$ 15$ million").

${ }^{3}$ See Barnes Indenture, supra note 10 , art. IX, I 10 (" $[\mathrm{N}]$ o picture belonging to the collection shall ever be loaned, sold or otherwise disposed of ....").

${ }^{39}$ See Richard, supra note 27, at G1. 
port the Foundation's existence, the trustees proposed exhibiting a portion of the collection during a worldwide tour. The terms of the Indenture specifically prohibited such a tour, ${ }^{61}$ and many Barnes supporters and art purists vehemently opposed the plan. ${ }^{62}$ These opponents ${ }^{69}$ claimed that the trustees never attempted to raise the needed funds in a manner consistent with Dr. Barnes's wishes. ${ }^{64}$

The court that heard the trustees' petition approved a one-time deviation from the Indenture's terms, determining that the deviation was administrative in nature $e^{65}$ and necessary to uphold the greater purpose of the Foundation-art education. ${ }^{\text {(i) }}$ Subsequently, the collection went on tour to venues including Tokyo, Paris and Washington, D.C. ${ }^{67}$ The trustees used funds which the exhibition generated to greatly "improve" the Foundation's facilities.

Following the tour's completion, the collection returned to its Merion, Pennsylvania home. Although the exhibition was a complete financial success, and the trustees no longer faced the dire financial

${ }^{6}$ See Hughes, supra note 11 , at 64 .

GI See Barnes Indenture, supra note 10, at art. IX, II 10, 13.

62 See Hughes, supra note 11 , at 64.

is Some of the most vocal opponents of Glanton's world tour proposal included New York art dealer Richard Feigen, and Thomas Freudenheim, the Smithsonian Institution's Under Secretary for Museums, both former board members of the Foundation's advisory committee. Additionally, a number of Barnes's present and former students opposed the tour. See id.

${ }^{64}$ Thomas Freudenheim said of the trustees, "They never tried to raise money. Some of us when we were naive, called the Getty Trust to see if they'd be interested and it could have worked. But it was the [F]oundation which was uninterested!" Osborne, supra note 13, at A24. Robert Hughes noted that "Glanton's critics object to the fact that the Barnes board never tried other ways of raising money-through charitable foundations or private donors. Selling out (as they see it) to the big museums is an admission of impotence...." Hughes, supra note 11, at 64.

${ }^{65}$ See In re Barnes Found., No. 58,788, slip op. at 16 (C.P. Ct. Montgomery County, Pa., Orphans' Ct. Div. July 21, 1992). For an examination of the administrative deviation doctrine in charitable trusts, see infra Part II.C.

See id. at 3, 7, 13.

${ }^{67}$ See Osborne, supra note 13, at A24-A25. It is interesting to note that the court also granted the trustees' petition to extend the world tour even after the requisite funds had been raised. See id.

${ }^{\text {is }}$ See Jennifer L. White, Note, When It's OK to Sell the Monet: A Truster-Fiduciay-Duty Framework for Analyzing the Deaccessioning of Ant to Meet Museum Operating Expenses, 94 MiCH. L. REV. 1041, 1062-63 (1996) (stating that the Barnes tour raised over $\$ 17$ million of which $\$ 12$ million was used to modernize the Foundation's facilities; the remaining $\$ 5$ million went toward its endowment and operating expenses); Kyle York Spencer, Reopening a Struggle for Bames, PHILA. INQUIRER, Nov. 11, 1995, at B1 (noting that the $\$ 12$ million in renovations included a high-tech security system, improved lighting, access for the disabled, fire protection and climate control). 
troubles that had motivated their first petition for deviation, the trustees successfully petitioned the court for numerous. other deviations from Barnes's mandates. ${ }^{6 \prime}$ The actions of the trustees remain the subject of court proceedings and government action. ${ }^{70}$

\section{The Misguided Trusteeship of the Barnes Foundation}

Albert Barnes and the Indenture he authored were bizarre, even unsettling. His investment restrictions left the Foundation in a state of disrepair and unable to independently fund necessary renovations. Nonetheless, the trustees apparently failed to give adequate consideration to fundraising opportunities that would have been consistent with the Indenture's conditions. ${ }^{71}$ The two plans the trustees devised, deaccessioning some of the art and the world tour, directly violated

69 On September 21, 1995, the Montgomery County Court of Common Pleas issued an order amending the Barnes Indenture. The trustees were given greater discretion to invest the Foundation's endowment and were allowed to expand public viewing of the Foundation to three-and-a-half days per week at an admissions fee of five dollars. See In re Barnes Found., No. 3231 Phila. 1995, 1996 Pa. Super. LEXIS 3155, at *6-7 (Pa. Super. Ct. Sept. 12, 1996). On appeal, the superior court did not grant the trustees' requests to raise admissions to ten dollars and to allow the gallery to remain open six days per week. See id. at *15. The superior court, however, reversed the lower court in part, and further amended the Indenture by permitting the trustees to hold fundraising events at the Foundation. See id. at *9-11; see also Robert W. Fowler, A ChaCha Near a Cezanne? Court Opens Bames Door, PHILA. INQUIRER, Sept. 14, 1996, at B1. In an earlier decision, the superior court also granted the trustees' petition to open the Foundation during July and August, which the Indenture also explicitly forbade. See Anne Barnard, Bames to Open for Summer, PHILA. INQUIRER, July 3, 1996, at B1.

${ }^{70}$ See Kyle York Spencer, Barnes Foundation Ordered to Cut Its Hours, PHILA. INQUIRER, Dec. 14, 1995, at B1. The township of Lower Merion, the Foundation's location, accused the trustees of transforming the Barnes into an art gallery, which conflicts with local zoning provisions that only allow for an educational institution. In an attempt to lessen the crowds caused by the Foundation's increased popularity, Lower Merion has ordered the Foundation to meet its zoning requirements by reducing the length and number of public visitation days. See id;; see also Anne Barnard, Barmes, $L$. Merion Go Back to Court over Zoning Dispute, PHILA. INQUIRER, Jan. 28, 1997, at B3 (noting that the Foundation will appeal a township zoning board decision which found "that the Barnes had illegally transformed itself from an art appreciation school ... . into a full-fledged museum").

${ }^{71}$ See supra note 64 and accompanying text. The decision by the court in the Barnes case should be viewed in light of principles established by the New Hampshire Supreme Court. Although not binding precedent, the decision is instructional in this area of the law: " $[D]$ eviation is allowed only for cogent reasons and only to the extent necessary to effectuate the primary purpose of the trust...." Jacobs v. Bean, 108 A.2d 559,561 (N.H. 1954). Logic tells us that the deviations undertaken by the Barnes trustees could only be deemed "necessary" if all alternatives permissible under the Indenture were explored and were unavailable. 
the Indenture. ${ }^{72}$

Even if the trustees tried and failed to raise the funds they deemed necessary for the Foundation's continued existence by means that did not violate the Indenture, the actions that the trustees undertook and that the courts approved are still inappropriate. Barnes clearly drafted provisions in the Indenture that instructed the trustees in the event conditions deteriorated to the point that the collection and Barnes's system of education became unmanageable. ${ }^{73}$ If the trustees determined that the "educational experiment" (in other words, the Foundation itself) was a failure, ${ }^{74}$ they were given the option of disposing of the collection by gift to another institution, school or museum. ${ }^{75}$ The Indenture does not provide for the transformation of the Foundation into a museum or for a two-year world tour. ${ }^{76}$

The trustees' inability to adhere to the conditions ${ }^{77}$ set forth in the Indenture constitutes a "failure" of Barnes's vision for the Foundation. Supporters of the trustees' actions argue that the basic purpose of the Foundation is educational and that the proscriptions and restrictions set forth in the Indenture are merely administrative and secondary. ${ }^{78}$ An examination of Barnes's life and philosophy, ${ }^{79}$ how-

${ }^{72}$ See supra notes 57-64 and accompanying text.

${ }^{73}$ See Barnes Indenture, supra note 10, art. IX, I 32. The Indenture states that the provisions of the Indenture could only be altered by the written consent of Dr. Barnes and that after his death no modification was permissible. See id.

${ }^{74}$ For a discussion of what constitutes the failure of a foundation as defined by the law, see infra Part II.B.

${ }_{75}^{75}$ See Barnes Indenture, supra note 10, art. IX, I 32.

${ }^{76}$ See id. Furthermore, the deviations undertaken by the trustees conflicted with the interests of the Foundation's intended beneficiaries-the students of the Barnes Foundation. With the collection on tour for two years, the students were unable to use the paintings for the intended educational purpose. Pennsylvania law prohibits deviation from a trust that impairs the interests of the trust's beneficiaries. See Lehigh Univ. v. Hower, 46 A.2d 516, 521 (Pa. Super. Ct. 1946) ("A court may vary specific instructions given by a testator in his will in order to accomplish the ultimate end which he had in view, provided such a departure does not impair the interest of any beneficiary or violate the testator's primary purpose.").

${ }^{77}$ For a discussion of the conditions that Barnes placed upon the Foundation, see supra notes $36-46$ and accompanying text.

${ }^{78}$ The Pennsylvania Superior Court that permitted fundraising at the Barnes also considered Barnes's restrictions to be mere administrative provisions. See In re Barnes Found., No. 3231 Phila. 1995, 1996 Pa. Super. LEXIS 3155, at*12-13 (Pa. Super. Ct. Sept. 12, 1996) (citing the elements necessary to deviate from the administrative provisions of a trust when deciding whether to allow an increase in admissions price).

${ }^{79}$ See supra notes 29-39 (discussing Barnes's contempt for his peers and the restrictions he placed on the Foundation as part and parcel of his educational philosophy). 
ever, clearly establishes that these conditions are more than just overreaching administrative tyranny mandated by Dr. Barnes. The conditions represent Barnes's overarching methodology and his intention as to how to perpetuate his Foundation. These conditions are mandatory, non-negotiable terms that the donor deemed necessary to guide the trustees in their management of his educational designs. Although unquestionably confining, these rules are integral to Barnes's charitable contribution. They should be honored to the fullest extent possible. ${ }^{80}$

More than anything else, the events subsequent to the collection's return to Merion highlight the lack of respect the trustees afforded to Barnes's wishes. ${ }^{81} \quad$ For example, the trustees successfully petitioned the court for permission to hold fundraising events in the Foundation's gallery. ${ }^{82}$ They expanded public viewing hours into the summer and increased admissions fees to the Foundation. ${ }^{83}$ These actions are blatant violations of the language of the Indenture as written by Dr. Barnes. ${ }^{84}$ Saddest of all is that these deviations and the attitudes of the trustees ${ }^{85}$ are clear indications that the Barnes Foundation has

${ }^{80}$ The one deviation from the terms of the Indenture that seems acceptable as purely administrative is the modification of the investment policies of the trust. Unlike the restrictions on the Foundation that deal with viewing privileges, the sale or loan of any paintings, and the use of the gallery as a public museum, the investment restrictions do not have any direct relationship to, or bearing on, Barnes's educational philosophy or his intentions regarding the proper role of the collection.

${ }^{81}$ See supra notes 69-70 and accompanying text.

${ }^{82}$ See supra note 69 . Prior to the superior court's order amending the Indenture and thus permitting fundraising events in the Foundation's gallery, the trustees held fundraising events on the Foundation's grounds. They successfully argued that the Indenture only prohibited social functions in the Foundation's buildings. See Leonard W. Boasberg, Court Allows Barmes' Guests at Dinner a Feast for Ejes, Too, PHILA. INQUIRER, Nov. 9, 1995, at Bl; see also Barnes Indenture, supra note 10, art. IX, I 33 . These events, although not direct violations of the language of the Indenture, show the trustees' obvious disregard for the wishes of Dr. Barnes.

${ }^{85}$ See supra note 69. Richard F. Glanton, president of the Foundation's board of trustees, argued that the Foundation is owned by the public and, as such, it should have a right to fully enjoy it. See Edward J. Sozanski, The Bottom Line at the Barnes Foundation: It's Now a Museum, PHILA. INQUIRER, Nov. 19, 1995, at F13. In fact, the Foundation is a private foundation, which must be accessible to the public and serve a charitable purpose in order to maintain its tax status. See id. Under Barnes's wishes, the Foundation would serve a charitable purpose, education for art appreciation, while remaining accessible to the public. There is no community ownership of the Foundation giving the public unlimited access to the collection.

See Barnes Indenture, supra note 10, art. IX, I 30.

${ }^{85}$ See, e.g., Osborne, supra note 13, at A24 ("Mr. Glanton [the Foundation's president] ... calls Mr. Barnes' [s] educational views "hokum."). The article also details the contemptuous relationship between Barnes and Walter Annenberg, another wealthy 
been transformed from an educational institution into a museum. ${ }^{86}$ In fact, the Lower Merion Township zoning board recently came to the same conclusion. ${ }^{87}$

The oddities of Albert Barnes and his visions for the Foundation may make any sympathy toward the man and his intentions difficult to foster. Nevertheless, it is important to remember that Barnes was never under any obligation to donate his collection for the public welfare in the first place. Respecting his demands and eccentricities was part of the bargain agreed to when his public charity was accepted. Moreover, objectivity demands that the law separate the bizarre circumstances surrounding this case from the real issue at hand-the failure of the legal system of trusteeship to value the wishes of the donor. Valid arguments that illustrate the societal need to respect donors' intentions ${ }^{88}$ should encourage the law to protect even those wishes considered irregular or bizarre.

\section{The LaW OF Charitable Foundations and DeViations From DONORS' WISHES}

\section{A. Defining a Charitable Foundation ${ }^{89}$}

"A foundation may be defined as a nongovernmental, nonprofit organization having a principal fund of its own, managed by its own trustees or directors, and established to maintain or aid social, educational, charitable, religious, or other activities serving the common

Philadelphian, whom Glanton made an honorary member of the Barnes advisory committee. See id. Annenberg has since resigned from the advisory committee. See Richard, supra note 27, at G4 (noting Annenberg's resignation in early April 1991).

${ }^{86}$ See Osborne, supra note 13, at A24 ("'Basically, the Barnes trust was set up to fund a charitable educational institution. What is happening now is that outsiders are coming in to turn it into a cash-cow commercial museum against Barnes' [s] express wishes." (quoting Nicholas Tinari, editor of the Barnes Watch newsletter)); Sozanski, supra note 83, at F13 (writing that the Foundation-under its current management, with renovations in place and the crowds it attracts-is undoubtedly a museum incompatible with the educational mission of its founder; Glanton hopes to draw 120,000 people annually while increasing admission fees and public viewing times).

${ }^{87}$ See Barnard, supra note 70, at B3 (noting that, upon this finding, the zoning board filed a complaint with the Merion County Court requesting that the Foundation be required to shorten its visiting hours and restrict the number of visitors allowed weekly).

${ }^{88}$ See infra Part IV.

${ }^{89}$ I use the terms charitable foundation and charitable trust interchangeably. All foundations can be legally classified as either charitable trusts, charitable corporations or charitable associations. See FISCH ET AL., supra note 3, § 36, at 35. 
welfare." ${ }^{\text {,90 }}$ A foundation such as the Barnes Foundation is a privately created and operated institution that serves the public in some manner.

A charitable trust is distinguishable from a private trust on a number of grounds. The beneficiaries of a private trust are normally a small number of identified or identifiable people." Thus, society as a whole has no interest in the trust. In addition, the private trust must be temporary in nature.

In order for a trust to be considered charitable, the trust must either be for the benefit of the community at large or for the benefit of a class of persons. Trusts that benefit a class of persons must be designated as an aid to the impoverished, or to education, religion, health or other charitable purpose. ${ }^{92}$ Only the charitable trust is exempt from the Rule against Perpetuities" and, in turn, is "potentially infinite in duration." ${ }^{94}$ Finally, for purposes of this Comment, it is important to realize that "foundations can be divided into those which give grants to other organizations or individuals, and those which operate their own programs."

The characteristics or privileges that distinguish foundations are

so ANDREwS, supra note 21, at 11.

${ }^{91}$ See id. at 48.

92 See DUKEMINIER \& JOHANSON, supra note 8 , at $587-88$ (explaining that a trust is not charitable merely because it benefits a class of people unless the designated class falls in one of the aforementioned categories). Andrews notes that although a charitable trust may benefit certain individuals, "it does not go for the purpose of mere enrichment, but rather to produce a desirable social effect.'" ANDREwS, supra note 21, at 48 (quoting GEORGE GLEASON BOGERT, THE LAW OF TRUSTS AND TRUSTEES $§ 361$ (1953)).

${ }^{93}$ The classic definition of the Rule Against Perpetuities is that "[n]o interest in real or personal property shall be good unless it must vest, if at all, not later than 21 years after some life in being at the creation of the interest." CAL. CIV. CODE $§ 715.2$ (West 1982). The idea behind the Rule is to limit "dead hand" control and to keep property marketable and available for the current demand. See CLARK ET AL., supra note 17, at 744-48; DUKEMINIER \& JOHANSON, supra note 8 , at 760-64. The Rule gives grantors some control over their property when devised, but prohibits current property owners from controlling the uses of their property indefinitely. See CLARK ET AL., supra, at 747-48 (citing LEWIS M. SIMES \& ALLAN F. SMITH, THE LAW OF FUTURE INTERESTS $\$ 1117$ (2d ed. 1956)). The charitable trust exemption from the Rule Against Perpetuities is significant in that the founder of a charitable trust can determine how her money or property will be used into perpetuity. Charitable trusts thus have a greater potential to preserve a donor's intent.

${ }^{94}$ Roger G. Sisson, Comment, Relaxing the Dead Hand's Grip: Charitable Efficiency and the Doctrine of Cy Pres, 74 VA. L. REV. 635, 635 (1988).

${ }^{95}$ ANDREWS, supra note 21, at 151 . Most foundations, especially the larger, more well-known funds like the Ford Foundation, distribute most of their funds through grants. See id. The Barnes Foundation is an example of an operating foundation. 
also the motivating factors leading to their establishment. ${ }^{96}$ Specifically, the foundation allows its creator to provide charitable funding while retaining control over the distribution and uses of her contributions. ${ }^{97}$ Another important factor is the tax benefits gained by using a foundation as a vehicle for charitable giving. ${ }^{98}$

This Comment's specific concern regarding charitable foundations is the departure from, or the alteration of, the wishes of philanthropists who establish foundations. Legally, these modifications can be categorized under two headings: (1) the $c y$ pres doctrine; and (2) administrative deviation.

\section{B. The Cy Pres Doctrine}

Cy pres is a shortened form of the phrase cy pres comme possible, which in Norman French means "as near as possible." The main objective of this charitable trust doctrine is to allow the donor's purpose to be followed as closely as possible when the donor's specific mandates cannot be carried out. ${ }^{100} \mathrm{Cy}$ pres is not a doctrine of convenience

${ }^{90}$ See id.

97 See FISCH ET AL., supra note $3, \S 42$, at 42.

98 The taxation of charitable foundations involves a complex set of rules and regulations. Because these tax consequences are not vital to this discussion, an explanation of these rules is not provided. For a detailed discussion, see Edward Jay Beckwith \& Jana S. DeSirgh, Technical Appendix: Tax Law and Private Foundations, in AMERICA'S WEALTHY, supra note 4, at 267, 267-93. Generally, the foundation has been a popular device because it gives the donor some of the tax benefits she would receive in giving her money to a nonfoundation charity. See FISCH ET AL., supra note $3, \S 42$, at 42 ("However, the role of the statutes... has probably been overemphasized since the tax deduction ... is less when he gives his property to a foundation than when he gives his property to a non-foundation charity ...."). For qualified gifts to charity, the Internal Revenue Code grants limited income, gift and estate tax deductions. See Mary Kay Lundwall, Inconsistency and Uncertainty in the Charitable Purposes Doctrine, 41 WAYNE L. REV. 1341, 1343-44 (1995) (citing I.R.C. $\$ \$ 170,642$ (c), 252, 2055 (1987)).

In addition to the preferential tax treatment afforded to charitable trust donors, charitable trusts themselves qualify as exempt organizations under federal tax law. Some or all of the income that foundations generate is tax exempt. See THOMAS L. WATERBURY, MATERIALS ON TRUSTS AND ESTATES 1017-1018 (1986). Tax incentives for the creation of charitable foundations were curtailed to some degree by the Tax Reform Act of 1969 and subsequent legislation. See Beckwith \& DeSirgh, supra, at 286-87.

${ }^{90}$ In re Estate of Buck, No. 23259 (Cal. Super. C. 1986), reprinted in 21 U.S.F. L. REV. 691, 747 (1987) (citing GEORGE G. BOGERT, TRUSTS AND TRUSTEES $\$ 431$, at 490 (2d ed. 1964)).

${ }^{100}$ See id. The cy pres doctrine is traditionally stated as follows:

If property is given in trust to be applied to a particular charitable purpose, and it is or becomes impossible or impracticable or illegal to carry out the particular purpose, and if the settlor manifested a more general intention to devote the property to charitable purposes, the trust will not fail but the court 
that allows courts to vary the terms of a foundation when such modification would make the trust more beneficial to the community or to the foundation itself. ${ }^{101}$ Judicial use of cy pres is reserved for those instances when a court determines that the particulars of a trust can no longer be followed (the specific intent), that is, when there is failure of purpose. ${ }^{102}$ If the court determines that the foundation can still effectuate the general charitable intentions of the donor, the court will allow the trustees to administer the trust through deviation from the specified instructions of the donor. ${ }^{103}$ The proper application of cy pres supports adherence to donor intent because it attempts to effectuate the wishes of the donor in the face of previously unforeseen obstacles.

General charitable intent is distinguished from the specific intent of a trust in that the former is "a desire to benefit a charitable purpose or objective rather than any particular object or institution."104 This distinction can best be illustrated through an example: Suppose a donor instructs her foundation to fund AIDS research being performed at the Mayo Clinic. Five years after the donor's death, the Mayo Clinic ceases its AIDS research. If a court determines that the donor's general charitable intent was to fund AIDS research, the court may use cy pres to modify the terms of the trust and allow the trust to fund AIDS research at other institutions. Suppose, however,

will direct the application of the property to some charitable purpose which falls within the general charitable intention of the settlor.

RESTATEMENT (SECOND) OF TRUSTS $§ 399$ (1959).

${ }_{101}$ See In re Estate of Buck, No. 23259 (Cal. Super. Ct. 1986), reprinted in 21 U.S.F. L. REV. 691, 749-56 (1987) ("The gy pres doctrine should not be so distorted by the adoption of subjective... standards such as 'inefficiency' or 'ineffective' philanthropy to the extent that it becomes a facile vehicle for charitable trustees to vary the terms of a trust....").

${ }_{102}$ See City of Danville v. Caldwell, 311 S.W.2d 561, 563 (Ky. Ct. App. 1958) (noting that $y$ pres will not be applied unless the specified purpose cannot be carried out, and then only if there is a showing of general charitable intent).

Reasons why the particular purpose mandated by a donor cannot be followed include: (1) insufficient funds; (2) impossibility; (3) nonexistence of the named beneficiary; and (4) unsuitability of the premises devised for the charitable purpose. See CLARK ET AL., supra note 17 , at 566.

${ }^{103}$ See Vanessa Laird, Note, Phantom Selves: The Search for a General Charitable Intent in the Application of the Cy Pres Doctrine, 40 STAN. L. REV. 973, 974 n.3 (1988) ("' [T] he judicial $c y$ pres doctrine may be resorted to, not to defeat the donor's intention, but to effectuate it" (quoting School Dist. No. 70 v. Wood, 13 N.W.2d 153, 157 (Neb. 1944))). Laird also notes that, "[b]y making modification of the trust contingent on the testator's charitable intent, cy pres suggests that, whatever the court does, it does with the consent of the phantom testator." Id. at 973-74.

${ }^{104}$ FISCH ET AL., supra note $3, \$ 575$, at 438. 
that evidence presented to the court establishes that the donor's specific and primary intention was that her funds only be used for the Mayo Clinic's AIDS research. In this instance, cy pres would be inapplicable and the court should not modify the terms of the trust. Determining whether a donor had a general or specific intent is usually quite difficult because donors rarely foresee or plan for the failure of their particular intentions or give instruction as to their general charitable intent. ${ }^{105}$

If a charitable trust can no longer be administered in accordance with the mandates of the grantor because of impossibility or illegality, and cy pres is inapplicable, the trust fails. ${ }^{106}$ Upon failure, property held in the trust reverts to the heirs of the donor unless she directed otherwise in her will. ${ }^{107}$ A donor may leave instructions for the disposition of the trust in the event of its failure. In such a case, those instructions should be determinative of the trust's future course, not the trustees' belief as to the donor's general charitable intent. ${ }^{108}$

Courts have traditionally been conservative in their use of the

${ }^{105}$ See id. $\$ 575$, at 439 ("The ascertainment of whether a donor had a general or particular charitable intention is seldom simple, for the donor generally fails to foresee the possible failure of his particular purpose.").

${ }_{106}$ See id. $\$ 659$, at 507 ("Equity has power to terminate when it becomes impossible, impractical or illegal to carry out the specific charitable purpose of a donor."). In Evans v. Abney, 396 U.S. 435, 444 (1970), the Supreme Court held that a trust that was established to create and maintain a segregated park on a plot of land in Macon, Georgia, violated the Equal Protection Clause of the United States Constitution. The Court determined that $c y$ pres could not be used to modify the trust to create a desegregated park, because this would have violated the specific intent of the donor, Senator Augustus $\mathrm{O}$. Bacon. Thus, the trust failed, and the property reverted to the donor's estate. FISCH ET AL., supra note $3, \S 659$, at 507-08.

It should be noted that the failure of a trustee to act in accordance with the intent of the grantor will not cause failure. In such a case, if the trust can be administered in accordance with the donor's wishes, the court will simply select another trustee. See FISCH ET AL., supra note $3, \S \S 660-61$, at 508-10 (discussing failure of a trustee and selection of a new trustee).

${ }^{107}$ See FISCH ET AL., supra note $3, \S 659$, at 508 ("When a disposition can be saved for charity only by the $c y$ pres doctrine, and that doctrine is not applicable or does not obtain in the jurisdiction, the property reverts to the heirs of the donor unless he has made other provision for its disposition." (citations omitted)).

${ }^{108}$ See Laird, supra note 103, at 978 ("[I]f the testator made express provision for the disposition of the trust in the event of failure, such provision is controlling under cy pres."). This idea has particular relevance to the Barnes case. Although the Barmes court stated that the deviations it permitted were only administrative, this Comment argued earlier that those deviations went to the very purpose of the trust. See supra Part I.C. As such, Barnes's instructions in the event of failure should have been controlling. See supra notes 73-75 and accompanying text (noting that Barnes called for the distribution of his collection in the event his educational experiment failed). 
power of $c y$ pres. $^{10 y}$ The prevailing attitude among academics today, however, is that $c y$ pres should be used more expansively to make foundations more beneficial to the public in light of changing societal needs and demands. ${ }^{10}$

\section{The Administrative Deviation Doctrine}

Administrative deviation must be distinguished from cy pres because the two concepts are often mistaken for one another. Deviations from the administrative terms of a trust may be excused when adherence to those terms would disrupt the specific purposes of the trust." Cy pres applies when the issue is whether the court can modify

${ }^{109}$ See, e.g., Trust Under the Will of Porter, 447 A.2d 977 (Pa. Super. Ct. 1982).

The meaning of the doctrine of $c y$ pres... is, that when a definite function or duty is to be performed, and it cannot be done in exact conformity with the scheme of the person or persons who have provided for it, it must be performed with as close approximation to that scheme as reasonably practicable....

Id. at 979 (emphasis added) (quoting Philadelphia v. Heirs of Stephen Girard, $45 \mathrm{~Pa}$. 9, 28 (1863)). The modern trend, however, is toward a narrower interpretation of $c y$ pres and the expansive use of other trust law doctrines (e.g., administrative deviation, discussed in the next section) to allow trustees to maintain the operation of charitable foundations. See FISCH ET AL., supra note $3, \S 589$, at 467 ("The strong desire to sustain charitable dispositions and entities whenever possible has now outpaced the strictures of the cy pres doctrine ...."); see also In re Barnes Found., No. 58,788 (C.P. Ct. Montgomery County, Pa., Orphans' Ct. Div. July 21, 1992). As previously discussed, the issue in the Barnes case arguably concerned the very intentions of the donor, but the decision ignored any reference to $c y$ pres, using instead the more liberal doctrine of administrative deviation to modify the trust. $I d$.

${ }^{110}$ See, e.g., C. Ronald Chester, Cy Pres: A Promise Unfulfilled, 54 IND. L.J. 407, 425 (1979) (arguing that courts "will best serve the interests of society in the charitable trust field by applying $c y$ pres widely and openly as a matter of public policy and by paying less regard to notions of individual intent"); Joseph A. DiClerico, Jr., Cy Pres: $A$ Proposal for Change, 47 B.U. L. REV. 153, 195 (1967) (arguing that an expansion of the gy pres doctrine should be within a court's equity powers); Alex M. Johnson, Jr. \& Ross D. Taylor, Revolutionizing Judicial Interpretation of Charitable Trusts: Applying Relational Contracts and Dynamic Interpretation to Cy Pres and America's Cup Litigation, 74 IOWA L. REV. 545, 568 (1989) ("What is needed is a reasoned doctrine for the application of $c y$ pres which takes into account not only the settlor's intent, but society's interest in the efficacious utilization of resources in light of changed conditions that occur following the donor's death.").

In the same vein, some legislators have expanded the use of $c y$ pres under the theory that it is better to sustain charitable gifts than it is to adhere to the strict ideology behind the doctrine of $c y$ pres. For example, Pennsylvania eliminated the general charitable intent requirement from its application of $c y$ pres. 20 PA. CONS. STAT. ANN. $\S 6110$ (a) (West Supp. 1996).

III See RESTATEMENT (SECOND) OF TRUSTS \$ 381 (1959).

The court will direct or permit the trustee of a charitable trust to deviate from a term of the trust if it appears to the court that compliance is impossible or illegal, or that owing to circumstances not known to the settlor and not an- 
the specific directions of a charitable foundation in order to uphold the general intent, whereas administrative deviation is exercised when the issue concerns the manner in which the trust is managed. ${ }^{112}$ Administrative deviation is used to perpetuate the viability of the donor's specific intentions. Thus, unlike $c y$ pres, there is no need to find a general charitable intent before permitting the deviation. ${ }^{\text {"1s }}$

The deviation doctrine has been used to increase the number of trustees of a trust, ${ }^{114}$ to permit the mortgaging of charitable property, ${ }^{115}$ to allow trustees to charge tuition, ${ }^{116}$ and to eliminate a racial restriction. ${ }^{117}$ The prerequisites for the usage of the doctrine are not settled. Some courts have been willing to apply the doctrine only in cases of near impossibility. ${ }^{118}$ The normal practice is to permit deviation when changed circumstances make adherence to the specific administrative terms of a trust possible but impractical. ${ }^{119}$

ticipated by him compliance would defeat or substantially impair the accomId.

plishment of the purposes of the trust.

${ }^{112}$ See Cy Pres and Deviation, supra note 16, at 398 (noting situations in which deviation has been used, such as in the modification of investment restrictions laid out in a trust document).

${ }^{11}$ See FISCH ET AL., supra note $3, \S 547$, at 407.

${ }^{114}$ See Reagh v. Hamilton, 78 P.2d 555, 558 (Wash. 1938) (upholding a trial court decree providing for a board of trustees with between three and nine members despite the fact that the will creating the trust provided for only three individual trustees, because the decree did not do "violence to the primary object of the testator").

${ }^{115}$ See Bond v. Town of Tarboro, 7 S.E.2d 617, 619-20 (N.C. 1940) (finding a $\$ 40,000$ mortgage to be within the power of the trustees insofar as it served the purpose of maintaining the trust's assets).

${ }^{116}$ See Coffee v. William Marsh Rice Univ., 408 S.W.2d 269, 286 (Tex. Civ. App. 1966) (allowing a deviation in order to permit the charging of tuition and acceptance of applicants without regard to race).

${ }_{11}$ See Bank of Delaware v. Buckson, 255 A.2d 710, 712, 717 (Del. Ch. 1969) (finding that a provision of a will naming "white youths" as eligible for a scholarship was written under a set of circumstances not present at the time the case was heard by the court, and therefore, the provision was not binding on the trustees).

${ }^{118}$ See, e.g., Wachovia Bank \& Trust Co. v. John Thomasson Constr. Co., 168 S.E.2d 358, 364 (N.C. 1969) (noting that deviation could be used to "modify the terms of a charitable trust when it appears that some exigency ... or emergency... has arisen requiring a disregard of a specific provision of the trust ... to preserve the trust estate").

119 See Cy Pres and Deviation, supra note 16, at 402 (citing Petition of Hershey Trust Co., No. 712 of 1963 (C.P. Ct. Dauphin County, Pa., Orphans' Ct. 1970), which permitted deviation on a finding that the trust requirements had become "inefficient, cumbersome and unresponsive to changing economic situations"').

The terms "impracticability" and "impracticality" are used throughout this Comment. These terms are not synonymous. The American Heritage Dictionary specifically highlights the difference: "Impracticable applies to a course of action that is impossible to carry out or put into practice; impractical... can be weaker in sense, 
The distinction between cy pres and administrative deviation seems readily identifiable on initial consideration. There are many instances, however, when the use of either doctrine is justifiable because it is unclear whether the issue relates to the trust's administration or its specific purpose. ${ }^{120}$ For example, Trustees of Dartmouth College v. Quincy ${ }^{121}$ dealt with a trust established to create and support a school for the education of women born in Quincy, Massachusetts. Because the trust did not provide enough funds to meet the costs of running the school, the trustees decided to admit women from other towns and to charge them a higher tuition. The court determined that this modification was administrative in nature and approved the action. ${ }^{122}$ An equally valid argument could have been made, however, that modifying the admissions policy affected the very purpose of the trust. With such a finding, cy pres would have been appropriate, but only if there was an additional finding of general charitable intentthat is, the general desire to create a school to educate women.

The preceding example demonstrates the ambiguity present in many cases in determining whether cy pres or administrative deviation is the appropriate doctrine. This ambiguity creates the opportunity for a trustee or a court with a specific agenda to characterize a situation under the doctrine most beneficial to the desired outcome. ${ }^{123}$

suggesting that the course of action would ... have little practical value." AMERICAN HERITAGE DICTIONARY OF THE ENGLISH LANGUAGE, supra note 2, at 908 . The common definition of $c y$ pres lists both impracticability and impossibility of purpose as acceptable reasons for application. See RESTATEMENT (SECOND) OF TRUSTS $\$ 399$ (1959). This usage suggests redundancy; however, Black's Law Dictionary notes that "commercial impracticability" is a "broadened interpretation of the doctrine of impossibility which holds that a party to a contract... will be relieved [of performance] when the premise ... on which the contract was based no longer exists due to unforeseeable events." BLACK'S LAW DICTIONARY, supra note 3, at 756. The standard has been further muddled by courts and commentators who list impracticality as grounds for the application of $c y$ pres. See FISCH ET AL., supra note $3, \S 576$, at $442 \&$ n.16, 444 $\mathrm{n} .21$ (listing court holdings that based the use of $c y$ pres on impracticality). As noted in the text, the use of impracticality in the application of administrative deviation is similarly unsettled. Nevertheless, recognizing the distinction between these terms is vital to the proposal of this Comment. This Comment advocates the conservative application of both $c y$ pres and administrative deviation based on impossibility (impracticability), but not impracticality. See infra Part V.B.

${ }_{20}$ See Cy Pres and Deviation, supra note 16, at 399 (noting that there are times when an issue cannot be clearly categorized as falling under either cy pres or administrative deviation).

${ }_{121} 258$ N.E.2d 745 (Mass. 1970).

122 See id. at 750-53.

${ }^{123}$ See FISCH ET AL., supra note $3, \S 549$, at $410-11$ (noting that courts are often careless in their use of one doctrine instead of the other and that some courts label alterations administrative in nature to avoid the requirements of $c y$ pres). 
Not surprisingly, this sort of manipulation goes to the very centerpiece of this Comment-the Barnes case.

The Barnes case was decided under the auspices of administrative deviation. ${ }^{124}$ The court found that the central purpose of the Foundation is the "advancement of education and appreciation of fine arts, and preservation of the collection therefor."125 The court held that the terms of the Foundation's Indenture prohibiting the lending and removal of paintings from the Foundation were merely administrative. Thus, deviations from these terms were acceptable and necessary to protect the actual purpose of the trust. ${ }^{126}$

While the central purposes of the Foundation are education and art appreciation, the deviations permitted by the Orphans' Court cannot be summarily dismissed as administrative. ${ }^{127}$ The world exhibition of the collection violated the express terms of the Indenture, which were clearly of major importance to Dr. Barnes, as evidenced by his explicit prohibition against any amendments to the central articles of the Indenture. ${ }^{128}$

The deviations undertaken by the Barnes trustees subsequent to the world tour have effectively transformed the Foundation into a museum, ${ }^{129}$ such that even if the deviations were properly considered administrative, the result has been to alter the central purposes of the Foundation. ${ }^{130}$ The results of this case are outside the powers of both cy pres and administrative deviation.

Cy pres and administrative deviation are necessary and constructive tools when used moderately. ${ }^{131}$ The underlying principle guiding

${ }^{124}$ See supra text accompanying notes 65-66.

${ }^{125}$ In re Barnes Found., No. 58,788, slip op. at 3 (C.P. Ct. Montgomery County, Pa., Orphans' Ct. Div. July 21, 1992).

${ }^{126}$ See id. at 16-17.

${ }^{127}$ See supra Part I.C.

${ }^{128}$ See id.

129 See supra note 86 and accompanying text.

${ }^{130}$ See id. Recall that Dr. Barnes provided for the dissolution of his Foundation and the distribution of the collection in the event that his educational experiment was a failure. The trustees' actions transforming the Foundation into a museum evidence their belief that the educational experiment was a failure. If the trustees are right in determining that the Foundation failed in its initial purpose, they are under obligation to follow Barnes's wishes and dissolve the Foundation. If the trustees are mistaken and the Foundation's educational purpose is still viable, they are wrong in making that purpose subservient to the Foundation's current usage-a tourist attraction.

${ }_{131}$ For example, the Barnes Indenture's investment guidelines were properly modified under administrative deviation. This change undoubtedly does not attack any of the purposes of the Foundation. Moreover, this change was necessary for the endowment to keep pace with inflation and to provide the funding needed to main- 
both concepts is the desire to best effectuate the intent of the trustor. Nevertheless, in the Barnes case and in many other instances, ${ }^{132}$ trustees deviate from donors' intentions-a practice not permitted under either doctrine because it distorts the entire purpose underlying charitable trusts.

\section{The Role of Trustees}

This Comment can be reduced to a simple discussion of the proper role of trustees. Trustees are endowed with specific powers and obligations granted and/or mandated by the document governing the trust, statutes and the common law. ${ }^{133}$ For example, the trustee of a charitable foundation has the power to grant leases in the charity's property, ${ }^{134}$ to mortgage the property, ${ }^{135}$ and to contract and incur expenses necessary to achieve the objectives of the foundation. ${ }^{136}$ The duties of a charitable foundation's trustee include the duty to "administer the charity fully and faithfully" in furtherance of its purpose ${ }^{137}$ and the duty to "protect the interests of the beneficiaries of the trust." ${ }^{\text {,138 }}$

The duties and powers described above help illustrate the general principles guiding trusteeship. A trustee is appointed and charged with administering a trust for the benefit of another (the beneficiary). The trustee has an obligation to serve the beneficiary. ${ }^{139}$ The trustee

tain the collection.

The use of $c y$ pres is proper when a factual basis clearly presents evidence of a donor's general charitable intent and when the specifics of an indenture become impossible or illegal to perform. For a prime example of such an instance, see the discussion of In re Estate of Tomlinson, 359 N.E.2d 109 (Ill. 1976), supra note 15. The use of impracticality as grounds for $c y$ pres, however, is too easily manipulated. See In re Estate of Buck, No. 23259 (Cal. Super. Ct. 1986), reprinted in 21 U.S.F. L. REV. 691, 749-53 (1987) (refusing to modify a trust on the basis of "efficiency" and defining "impracticability" strictly); City of Danville v. Caldwell, 311 S.W.2d 561, 563 (Ky. 1958) (noting that "cy pres... is not applied unless the particular... purpose is incapable of performance").

${ }^{132}$ See infra Part III.

199 See FISCH ET AL., supra note $3, \S \S 457,511$, at $361-64,389-90$ (describing the powers of a charity and the duties of a trustee).

${ }^{194}$ See id. $\$ 459$, at 366 .

${ }^{195}$ See id. $\$ 460$, at 367 (explaining that managers have the power to mortgage charitable property if such authority is granted expressly or impliedly in the governing instrument or by statute).

${ }^{196}$ See id. $\$ 461$, at 368 .

${ }^{137} I d . \$ 513$, at 391 .

138

Id. $\S 521$, at 403 .

159

See BLACK'S LAW DICTIONARY, supra note 3, at 1514. 
of a charitable foundation, however, must do more than administer the trust in the way she believes will be most advantageous to the beneficiaries. She also has a duty to follow the intentions and directions of the creator of the foundation in serving the best interests of the beneficiaries. ${ }^{140}$ Obviously, a trustee should be afforded a fair amount of discretion. The role of the trustee often calls for judgment in the face of ambiguity or uncertainty. ${ }^{141}$ Discretion and deviation, however, are not synonymous. A trustee's discretion to deviate from the express language of a trust document should be guided by the desire to maintain the underlying purpose of the trust. ${ }^{142}$ The New Hampshire Supreme Court explained this scenario as follows:

"The court will direct or permit the trustee to deviate from a term of the trust if owing to circumstances not known to the settlor and not anticipated by him compliance would defeat or substantially impair the accomplishment of the purposes of the trust, and in such case, if necessary to carry out the purposes of the trust, the court may direct or permit the trustee to do acts which are not authorized or are forbidden by the terms of the trust." ${ }^{143}$

Once again, the relevant issues are the purpose of the trust and necessity. An understanding of the proper role of the trustee in a charitable foundation, along with the other principles discussed in this Part, strengthens the position of this Comment as to the Barnes controversy and similar situations.

${ }^{140}$ See H. Thomas James, Perspectives on Internal Functioning of Foundations, in THE FUTURE OF FOUNDATIONS 192, 193 (Fritz F. Heimann ed., 1973). James stated that "trustees of endowed wealth are legally and morally responsible for the honest, prudent management of the monies under their control. The most basic principle guiding their duties is loyalty, both to the preservation and to the purposes of the trust." Id.

${ }^{141}$ See Harris v. Attorney Gen., 324 A.2d 279, 283 (Conn. Super. Ct. 1974).

"Where discretion is conferred upon the trustees of a charitable trust, the court will not interfere with the exercise of their discretion, except to prevent an abuse of discretion.... If the trustees act within the bounds of [a] reasonable judgment in the exercise of the discretion conferred upon them, the court will not interfere."

Id. at 283 (omission in original) (quoting IV AUSTIN WAKEMAN SCOTT, THE LAW OF TRUSTS $\$ 382$ (3d ed. 1967)); see also FISCH ET AL., supra note 3 , $\$ 476$, at $384-86$ (discussing the discretionary powers of trustees).

${ }_{142}$ See FISCH ET AL., supra note $3, \S 476$, at 385 (noting that "the discretionary powers of the ... [trustee] must be exercised in such a manner as to further the charitable purposes of the entity" and that "courts will interfere with the discretion of those managing a charity [when there] 'is ... substantial departure ... from the dominant purpose of the charity." (quoting Taylor v. Baldwin, 247 S.W.2d 741, 750 (Mo. 1952))).

${ }^{143}$ Jacobs v. Bean, 108 A.2d 559, 561 (N.H. 1954) (emphasis added) (quoting RESTATEMENT OF TRUSTS $§ 167(1)(1935))$. 


\section{DeVIATING From DONORS' WISHES: A COMMON OCCURRENCE}

The Barnes Foundation is not the only case where the trustees of charitable trusts have inappropriately ${ }^{144}$ deviated from the intentions of the donors who created them. Noted author Martin Wooster devoted an entire book to exposing trustees' disregard for the wishes of some of this nation's greatest philanthropists. ${ }^{145}$ This Part provides a brief examination of a few of these instances. They are a comparative tool for the study of the Barnes case and donor intent in general.

\section{A. The Ford Foundation and the Carnegie Corporation}

The Ford Foundation is the largest charitable foundation in the United States. ${ }^{14 \hat{j}}$ Wooster notes that Ford donated over one-third of his income to charity, making him far more generous than his entrepreneurial peers or the average American at the time. ${ }^{147}$ Ford, however, developed a strict philosophy for giving. His belief in selfreliance was reflected in his motto for giving, "a chance and not charity."148 Ford's belief in self-help, coupled with his disdain for government and its welfare projects, guided his charitable ambitions. His idea of charity was to give people jobs and a chance to be productive. ${ }^{149}$ Nevertheless, Ford left no instructions on how the Foundation's funds should be administered following his death. ${ }^{150}$ Ford's carelessness has given the Foundation the opportunity to fund programs that Ford would have diametrically opposed. ${ }^{151}$ Today, the Foundation repeatedly funds government studies and liberal causes. ${ }^{152}$

144 The deviations undertaken by the Barnes trustees were sanctioned by a court order and, thus, were not inappropriate in the sense of being unlawful. This Comment argues, however, that the court and trustees acted improperly because they did not adequately consider the intentions of Dr. Barnes.

${ }^{143}$ See WOOSTER, supra note 26.

146 See Salisbury, supra note 8, at A26 (charting the size of the ten largest foundations (citing the Foundation Center)). As of 1994, the Ford Foundation had $\$ 6.6$ billion in assets-almost $\$ 600$ million more than the next largest foundation-the Kellogg Foundation. See id.

147 See WOOSTER, supra note 26 , at 14.

148 Id. at 18.

149 See id. at 15-18 (noting that Ford believed in supporting projects that allowed the needy to be productive members of society).

${ }_{150}$ See WALDEMAR A. NIELSEN, THE GOLDEN DONORS 17 (1985).

151 See McMenamin, supra note 13, at 172.

152 See id. (noting that the Foundation's "pet project: the Center for Community Change [is] a Washington D.C. outfit that promotes big government and higher taxes ${ }^{n}$ ). 
Like Henry Ford, Andrew Carnegie deplored the concept of paternalistic government. ${ }^{153}$ He believed in aiding those who wanted to help themselves and those who could not help themselves. ${ }^{154}$ Also like Ford, Carnegie created his charitable corporation (the equivalent of a foundation) without giving it much instruction. He did, however, instruct the trustees to "best conform to [his] wishes by using their own judgment" ${ }^{\prime 155}$ when determining the Corporation's future funding policies. After Carnegie's death, the Corporation slowly drifted away from his principles of charity and instead increased funding for governmental welfare programs. ${ }^{156}$

\section{B. The Buck Trust}

Beryl Buck inherited her wealth from her husband's position in the family oil business. She donated approximately $\$ 10$ million in stock to care for the impoverished of Marin County, California, ${ }^{157}$ where she spent the last thirty-seven years of her life. ${ }^{158}$ The Marin Community foundation's holdings grew tremendously in the ten years following Buck's death in 1975 and are presently worth over $\$ 400$ million. ${ }^{159}$ The trustees of the foundation, seeing the enormous increase in the size of the Trust, decided to expand the foundation's charitable activities beyond Marin County, which had become a relatively wealthy region. ${ }^{160}$ They argued that Mrs. Buck never anticipated the tremendous growth of the Trust and that limiting the Trust's expenditures to Marin County would be wasteful. In the ensuing court battle, the trustees lost. The court held that efficiency gains could not be considered ${ }^{161}$ and that no grounds for implementing $c y$ pres existed,

153 See id.

154 See WOOSTER, supra note 26, at 29.

155 Id. at 31.

${ }^{156}$ See NIELSEN, supra note 150, at 134 (stating that the Carnegie Corp. has become the quintessential liberal, activist, entrepreneurial foundation); McMenamin, supra note 13, at 172 (noting that the Foundation mainly funds social engineering programs such as the Children's Defense Fund, which promotes expansion of government services).

${ }_{158}$ See McMenamin, supra note 13 , at 174.

158 See WOOSTER, supra note 26, at 53.

159 See DUKEMINIER \& JOHANSON, supra note 8, at 617.

${ }^{160}$ See WoOSTER, supra note 26, at 53 (noting that when Mrs. Buck settled there, Marin County was mostly farmland, but when she died, it was one of America's wealthiest counties); Laird, supra note 103, at 981 (noting that the trustees sought permission to spend the Trust throughout the San Francisco Bay Area).

${ }^{161}$ Recall from Part II.B that the doctrine of cy pres may be applicable where a particular charitable purpose becomes impossible or illegal to carry forward. The Buck 
thus preserving the donor's intent. ${ }^{162}$

\section{Comparing Ford, Carnegie, and Buck to Barnes}

The cases documented in this Comment are not the only incidents of trustee disregard for donors' intentions. ${ }^{163}$ Rather, these cases are included to highlight the many differing circumstances under which donors' intentions are disregarded by the trustees who administer their foundations. Each instance of donor intent presents its own issues and problems. The best way to illustrate this fact is to compare the Barnes Foundation with the other foundations this Comment reviews. The problems with Ford and Carnegie are distinguishable from the problems of Barnes and Buck in that the donors in the former cases did not leave detailed instructions as to the uses of their foundations' funds. In this sense, Henry Ford and Andrew Carnegie contributed to the trustees' disregard of their intentions by naively assuming that their foundations would follow their personal philosophies for giving. Because Ford and Carnegie neglected to leave detailed instructions, the deviations from their donative intent are not products of the application of $c y$ pres or administrative deviation or any judicial determination. Unlike the Barnes and Buck trustees, the Ford and Carnegie trustees are able to deviate without permission or interference from the courts. These latter trustees need no legal justification to pursue their own interests at the expense of the donors' wishes.

Barnes is distinct from Buck because Buck dealt with a question of cy pres-altering the very functioning of the trust-whereas the Barnes decision was couched in terms of administrative deviation. All of the aforementioned cases can be further distinguished from the Barnes case with the argument that the Barnes deviation grew out of economic need; ${ }^{164}$ in the other cases, the deviations were solely a product

court properly noted that the inefficiency of trust expenditures does not fall within these defined limits for the application of $c y$ pres. The court recognized the ambiguity of inefficiency as grounds for trust modification. Moreover, the court noted that impracticability is actually equated with impossibility for $y$ pres consideration. See In re Estate of Buck, No. 23259 (Cal. Super. Ct. 1986), reprinted in 21 U.S.F. L. REV. 691, 74655 (1987).

${ }^{162}$ See id. at 759-61 (concluding that Marin County still has needs that go unfulfilled, even with the Trust's funding, such that the purpose of the Trust is still viable).

${ }^{163}$ See generally WOOSTER, supra note 26, at 14-60 (discussing many other instances where donor intent is routinely violated).

${ }^{164}$ The Barnes Foundation was in an obvious state of disrepair with little financial support prior to its world exhibition. Critics of the tour and of the subsequent devia- 
of differing philanthropic philosophies, ${ }^{165}$ making them more obvious instances of disregard for the wishes of the donors.

Nevertheless, this discussion of Ford, Carnegie and Buck is included because these cases demonstrate an underlying similarity with the Barnes case-wayward trusteeship. Despite their factual differences, the ultimate sources of neglected donor intent in each instance are trustees that do not uphold the ideals of the people who established the foundations.

\section{The VALUE OF UPHOLDING DONOR INTENT}

The preceding three Parts of this Comment are anchored in the underlying assumption that donors' wishes should be routinely deferred to unless extraordinary circumstances arise. As such, this Comment has argued against a liberal application of $c y$ pres or administrative deviation to alter the course of a philanthropic foundation. ${ }^{166}$ More expansively, this Comment has questioned the propriety of deviations from donor intent that are accomplished without resort to any doctrinal justification. ${ }^{167}$

Because donative intent and the related issue of dead hand control are among the most controversial and often-debated topics in trusts and estates law, competing perspectives and assertions should be properly acknowledged. Assuming the primary objective guiding the law of charitable foundations is their positive impact on society, all sides of the issue must be considered to determine the best course for the law to follow. Unless the benefits that accrue from a commitment to donative intent outweigh the gains that can be achieved from liberal deviation, there is little reason to safeguard the wishes of philanthropists.

The most basic argument for respecting donor intent is that trus-

tions undertaken by the trustees have argued, however, that the economic need justification was merely a convenient vehicle used by the Barnes trustees to implement their own agenda for the Foundation. See supra Part I.B-C (noting the claim that the trustees never attempted to raise the needed funding by means that would not violate Dr. Barnes's intentions).

${ }^{165}$ The Ford, Carnegie and Buck donor-intent issues did not involve economic need. In fact, the Buck dilemma supposedly came about because the Trust had too much money for its intended purpose.

${ }^{166}$ See supra note 131 and accompanying text. See generally supra Part II.D (discussing general principles of trusteeship).

${ }^{167}$ See supra Part III.A \& C. Because Ford and Carnegie did not expressly mandate adherence to their charitable intentions, the trustees of these foundations freely deviated from the charitable philosophies of the trustors without legal impediment. 
tees have a moral and legal responsibility to respect the wishes of trustors. $^{168}$ This argument may emanate from the American ideology valuing capitalism and the right to property. A donor's right to have her intentions respected by her trustees, one may assert, is an extension of a donor's rights in the property donated. The donor accumulated the wealth, thus the donor has earned the right to voice her expectations and to direct the charitable disposition of that property.

Although compelling, this simplistic argument cannot be the only basis on which the protection of the intent of donors relies. Just as the trustees of a foundation have a responsibility to the trustor, they also have a moral and legal obligation to the beneficiaries of the trust. ${ }^{169}$ And in certain circumstances, trustees may argue that their obligations to their beneficiaries demand that they deviate from the wishes of the donor. ${ }^{170}$ The strongest justifications for either valuing or dismissing donative intent lie beyond the morality and legality of the issue. The superior policy is the one that maximizes the benefits society receives from charitable donations.

This Comment previously highlighted the salient features of charitable foundations: (1) their potentially limitless duration-they are exempt from the Rule Against Perpetuities; and (2) their tax exempt status-the exemption of income generated by foundations and the tax deductions given to their donors. ${ }^{171}$ These features create social costs. By providing these exemptions, society effectively subsidizes the perpetual activities of foundations regardless of the benefits to society. ${ }^{172}$

According to one opponent of dead hand control, because society

${ }^{163}$ See WOOSTER, supra note 26, at 124 (suggesting that foundation officers should respect the dead and give grants that are consistent with their founders' views); Atkinson, supra note 23, at 1121 (identifying the argument that disregarding donors' intent is inherently wrong).

${ }_{109}$ See supra Part II.D (discussing the proper role of trustees).

${ }^{170}$ For example, a trust could be established with instructions from the donor to "provide housing to the needy." At some future time, the trustees may argue that although the needy could still use housing, they have a greater, more imminent need for food. Morally then, is it not better for the trustees to deviate from the intent of the donor and use the trust funds to purchase food for the needy?

Please note that this Comment often discusses trustees' deviations. Implicit in these discussions is that trustees have court approval when required. This Comment does not intend to imply that trustees who deviate from donors' wishes do so unlawfully, circumventing the proper judicial procedures.

171 See supra Part II.A.

172 See WATERBURY, supra note 98, at 1017-18 (detailing the charitable trust exemption from the Rule Against Perpetuities and the favorable tax treatment given to such trusts). 
"pays" for the benefits that charitable foundations provide, the balance between donor intent/property rights and the common good should lean in favor of the common good. ${ }^{173}$ Extending this argument, opponents of dead hand control assert that donor control over charitable donations should be limited to the same extent that control over private gifts is curtailed. ${ }^{174}$

This Comment does not quarrel with the proposition that charitable foundations should be governed by those principles that attempt to extract the maximum societal benefits. The claim that adherence to donor intent and the common good are inversely related or even mutually exclusive, however, is a fallacy. In isolated instances, abiding by donors' wishes may seem to diminish the potential benefit that a foundation provides. Nonetheless, as the following discussion will illustrate, in most cases the protection of donor intent actually maximizes the public welfare that foundations can provide.

\section{A. Efficient Philanthropy}

\section{Donor Knows Best}

A popular notion among academic commentators is that strict adherence to donor intent leads to the inefficient use of funds by charitable foundations. ${ }^{175}$ Their basic argument is that charitable trust law allows a donor to specify how her foundation's funds will be administered throughout the life of the foundation, ${ }^{176}$ and since a foundation can be perpetual in duration, ${ }^{177}$ a charitable trust is often controlled by the "dead hand." Dead hand control, it is argued, is inefficient and even wasteful because donors rarely account for the changing needs and values of society. ${ }^{179}$ These commentators propose a more liberal approach to charitable trust administration. ${ }^{18}$

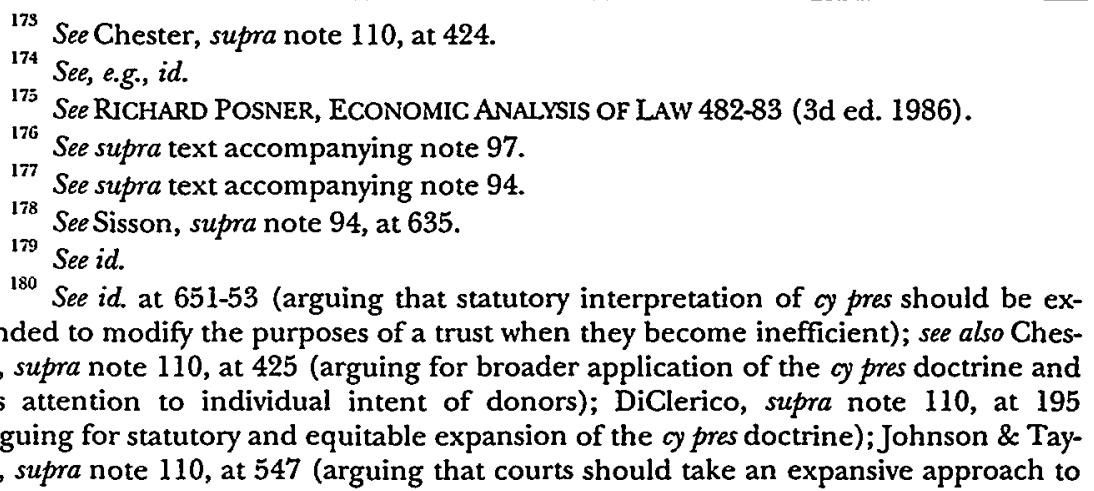


They assert that charitable trusts should be flexible so as to maximize the benefit to the public. Relying on this rationale, several legislatures have enacted more liberal versions of $c y$ pres and many courts have construed the cy pres doctrine more expansively, in an attempt to further their view of the public interest. ${ }^{181}$

This efficiency argument is compelling on its face, but when examined for practicality and consequence, it is flawed. To recognize the problems with the efficiency approach it is necessary to ask several questions: What is an efficient use of resources? How can society and the law best maximize a foundation's benefit to the public? Who should determine society's best interests? Are those who propose an efficiency standard prepared to carry their argument to its conclusion?

An efficient use of resources is that which has the greatest value to society or that which maximizes the benefit to the public. ${ }^{182}$ Thus, the test for efficiency is inherently subjective, and determining the best interest of the commonwealth depends on each person's concerns and values. Recognizing that each person's perception of society's needs and problems is subjective leads to the conclusion that "the maximum benefit to society" is equally as subjective. ${ }^{183}$ There is no "correct" answer to the question of what is the efficient use of funds. Whoever controls the distribution of a foundation's funds will make an individualistic determination of what the best interests of society are.

If society embraced a slightly altered view of charitable efficiency-the concept of relative need-trustees would follow a policy of directing charitable funding to those people or causes with the greatest need. ${ }^{184}$ Even putting aside the recurring problem of subjectivity and assuming that there is an objective hierarchy of needs, allowing trustees to allocate trust funds based on that hierarchy of needs would lead to a conclusion that is unrealistic and even destructive: "[A]ll charitable gifts, and the fundamental basis of philan-

cy pres by balancing the interests of the settlor, unintended beneficiaries and community in the efficacious use of the trust assets).

181 See FISCH ET AL., supra note $3, \S 589$, at 467 (noting that some states, including Pennsylvania, have eliminated the general charitable intent requirement and that some courts avoid the use of $c y$ pres altogether in order to give trustees greater discretion).

See In re Estate of Buck, No. 23259 (Cal. Super. Ct. 1986), reprinted in 21 U.S.F. L. REV. 691, 751-52 n.6 (1987).

iss See id.

${ }^{184}$ See id. 
thropy would be threatened, as there may always be more compelling 'needs' to fill than the gift chosen by the testator." ${ }^{185}$

For example, a foundation specifically established to serve the poor of Philadelphia might fail or be challenged on the grounds that there are poorer people with greater needs in the Appalachian region of Kentucky. A foundation that funds AIDS research might be challenged on the grounds that cancer research is more valuable. One might argue that the Barnes Foundation might serve the public need better (and be more efficient) if it were run as an art museum rather than as an educational institute. Courts would then be required to consider social utility and to "substitute their judgments or those of the trustees for those of the donors." ${ }^{186}$ The litigation concerning such issues would be endless, and the administrative costs of these reallocations would be enormous. Consequently, the time and money wasted determining how money would be best spent (assuming that issue is ever really determinable) would most likely negate the reallocative gains desired.

Since philanthropists establish foundations and provide for their funding, does it not follow that we should adhere to their ideas of society's best interest? Moreover, adherence to donors' intentions is the best way to minimize administrative and legal costs and to maximize the funds actually distributed to the beneficiaries. ${ }^{187}$

This Comment does not advocate blind adherence to the objectives of the donor. If a donor's intentions for a foundation or her administrative guidelines become impossible, impracticable or illegal, then the law allows trustees to exercise prudent discretion ${ }^{188}$ while always considering the donor's philosophy. ${ }^{189}$ The position of this Comment is simply that deference toward and respect for donors' intent should remain a guiding principle in the administration of charitable foundations.

185 Id

$186 \mathrm{Id}$

187 Allowing trustees greater discretion over trust administration will lead to an increase in conflicts like the Barnes case. In resolving these conflicts, foundations waste valuable resources on legal expenses. Similarly, granting trustees greater power over trusts leads to increased administrative time and expense.

${ }^{188}$ See supra Part II.D (discussing the proper role of trustees); see also In re Estate of Buck, No. 23259 (Cal. Super. Ct. 1986), reprinted in 21 U.S.F. L. REV. 691, $751-52$ (1987) (noting that inefficiency does not constitute impracticability under the cy pres doctrine and that something becomes impracticable only if it would fail to accomplish the general charitable intention of the donor).

${ }^{89}$ See supra Part II.D. 


\section{The "Rational Donor" Theory}

Building on the questionable theme of efficiency maximization raised by opponents of dead hand control, Richard Posner asserts that "rigid adherence to the letter of donative intent is likely to frustrate a donor's purpose." 190 Posner contends that a rational and reasonable donor would not intend for her gift to perpetuate if the purposes of that gift become useless or inefficient. A rational donor would actually prefer modification of her gift when it is no longer efficient. ${ }^{191}$ Posner posits that a rational donor knows that her intentions may be thwarted by unpredictable circumstances and may be presumed to implicitly accept deviations. ${ }^{1 / 2}$

Jonathan Macey countered Posner's claims on a number of fronts. ${ }^{193}$ Macey noted that overregulation and liberal modifications of settlors' rights to dispose of their wealth may be inefficient because such policies interfere with one incentive for wealth accumulationthe ability to influence society after death by directing the disposition of property. ${ }^{1.44}$ In the context of discussing the application of $c y$ pres to charitable trusts, Macey claimed that when "significant aspect[s] of a settlor's intentions are thwarted" ${ }^{195}$ by unforeseen circumstances, the most efficient solution is not modification but reversion of the gift back to the settlor's heirs. ${ }^{196}$ Macey questioned Posner's premise that settlors cannot prepare or plan for the unexpected. ${ }^{197}$ Macey claimed that donors may be able to leave charitable gifts that provide extensive contingency plans and the like in the event of changed conditions. Donors may not specify, however, all possible contingencies because the related transactions and error costs may render such planning inefficient. ${ }^{198}$ In other words, donors may not implicitly condone deviations from their charitable donations to avoid inefficiency or uselessness. Instead, donors may recognize the costs of planning for the unforeseen and decide that the most efficient way to deal with that situation is reversion of the gift.

190 POSNER, supra note 175 , at 482.

191 See id. at 482-83.

192 See id.

193 See Jonathan R. Macey, Private Trusts for the Provision of Private Goods, 37 EMORY

L.J. 295 (1988).

194 See id. at 297.

${ }^{195} I d$. at 306.

196 See id.

197 See id. at 298.

198 See id. at $297-98$. 
Macey's underlying premise is that the "goals of the legal system should be to establish rules that reduce the incidence of transaction costs, error costs, and agency costs associated with the creation of a trust." $^{\text {"ys }}$ A legal system that permits liberal application of $c y$ pres or administrative deviation increases the costs of establishing foundations to donors who want to safeguard their charitable foundations. ${ }^{200}$ Furthermore, as noted in the previous section, deviation leads to litigation costs, and administrative and reallocative expenses.

As Macey demonstrates, efficiency is actually better served by reversion than by modification. As a result, courts should attempt to effectuate donor intent and minimize the costs associated with deviations. When donative intent can no longer be followed, cy pres and deviation should be applied conservatively, recognizing that reversion is often the most efficient alternative.

\section{B. Respect for Donor Intent: A Necessary Incentive}

Society limits the dead hand control of trustors when their dispositions are private in nature. ${ }^{201}$ When people create charitable trusts, however, the law permits extended dead hand control. ${ }^{202}$ This exception can best be described as a bargain: as an incentive for people to donate their wealth for the public welfare, the law permits them to specify the use of that gift perpetually. ${ }^{203}$

Without extensive donor control over foundation administration, the use of foundations as a vehicle for philanthropic activities is likely to diminish greatly. ${ }^{204}$ Some opponents of donor intent may claim that with or without the use of foundations, the wealthy will still give

${ }^{199} I d$. at 320 .

200 See id. at 302.

201 See generally UNIF. STATUTORY RULE AGAINST PERPETUITIES, in SELECTED STATUTES ON TRUSTS AND ESTATES 490-552 (John H. Langbein \& Lawrence W. Waggoner eds., 1987); supra note 93 (defining the Rule Against Perpetuities).

${ }^{202}$ See Atkinson, supra note 23, at 1114 (stating that, with respect to charitable gifts, the "state not only allows perpetual dead hand control, but also monitors and enforces it").

${ }_{203}$ See id.

${ }^{204}$ See FISCH ET AL., supra note $3, \S 42$, at 42 (suggesting that foundations are used as a means for the creator to commit her funds to a charitable use of special interest to her); Odendahl, supra note 22, at 236 (noting that surveys show that control is a primary motivating factor for the creation of charitable trusts). If this primary motivation for the establishment of foundations is taken away, foundations lose a major advantage. Consequently, donors will look to other charitable vehicles for the benefits they offer, or they will reduce their charity altogether. 
to charity and therefore the "inefficient" bargain ${ }^{205}$ should no longer be a part of charitable trust law.

Two questions arise from this claim: (1) Would the wealthy give as much to charity regardless of their use of foundations, knowing that they could not "control" their charitable gifts forever?; and (2) Assuming that potential donors would give to charity with the same level of generosity regardless of the control they could maintain over their gifts, are there distinctive benefits derived from foundations, such that we should encourage their continued use?

\section{Generosity Is Related to the Level of Control}

Without control over their charity, some philanthropists would decrease their level of giving. ${ }^{206}$ Knowing that their fortunes may be put to uses of which they disapprove or even despise, ${ }^{207}$ some donors may forego public charity altogether, choosing instead to squander their money during their lifetimes or to bequeath it to friends and family. Therefore, to encourage people to keep giving funds that benefit the public, the law must respect and uphold the wishes of donors even when those wishes are unpopular or seem unwise.

Jonathan Macey provides insight that further illuminates the likelihood that charity is related to the level of control. Modifications are often permitted on the assertion that they are minor or that they do not affect the "dominant purpose of the gift." ${ }^{208}$ Courts and trustees may argue that such modifications are necessary to carry out the broader purposes of the trust and intentions of the donor. This ar-

${ }^{205}$ By "inefficient" bargain, this Comment is referring to the extension of dead hand control as an inducement for charitable generosity in the form of public trusts.

${ }^{206}$ See Atkinson, supra note 23, at 1121 (stating that "once donors know their intentions can be disregarded without legal penalty, they will be less inclined to give"); Osborne, supra note 13, at A25 ("If a will isn't sacrosanct under the law, what is? The Fricks, Barneses and Carnegies of the future are going to think very carefully before donating ... to our future generations." (quoting Thomas Freudenheim, the Smithsonian Institute's Under Secretary for Museums)). Recall also that charitable foundations provide over $\$ 6$ billion annually to nonprofit organizations. See supra note 8 (noting the large number of foundations with distributions totalling in the billions of dollars). If the overall level of generosity of America's wealthy diminished by even a few percentage points, the decrease in charitable donations would be enormous in dollar amounts.

207 See supra Part III.A.

${ }^{208}$ Macey, supra note 193, at 304. See generally In re Barnes Found., No. 58,788, slip op. at 16 (C.P. Ct. Montgomery County, Pa., Orphans' Ct. Div. July 21, 1992) (noting that the Court may permit administrative deviations to protect the "accomplishment of the purpose of the Trust"). 
gument ignores the fact that grantors usually have a range of options as to how to dispose of their property. ${ }^{203}$ The utility that a donor receives from a charitable donation of her property may be only marginally higher than the donor's utility from a private disposition of her property. When donors believe that their intentions can be easily thwarted through supposedly minor or inconsequential deviations, the marginally higher utility they receive from the charitable dispositions may vanish. Consequently, some donors may dispose of their property privately.

Macey's argument is applicable to the Barnes Foundation. If $\mathrm{Al}-$ bert Barnes knew that his Foundation would become an art museum and that many of his demands for the administration and disposition of the collection would be ignored or modified, would he have even created the Foundation or donated his art to charity in the first place? Recognizing the possibility that their intentions will be trampled upon, how many future philanthropists will decide to forego charitable donations?

\section{The Distinct Benefits of the Foundation}

W.J. Hume made an interesting observation regarding donor intent. He said that "[a] major inflow of funds into philanthropic institutions will occur within the next two decades. Those who made their money after World War II will reach maturity, and their estates will be passed to their heirs and to foundations." 210 Assuming Hume is correct, the issue of donor intent is as important now as ever. How this impending wealth distribution is allocated between private and public donations cannot be foreseen with any certainty. Similarly uncertain is whether those settlors committed to the public welfare will use the foundation or some alternative charitable mechanism as their mode of giving. One thing is certain-disregard for donor intent diminishes the attractiveness of the charitable trust to potential donors. Therefore, society must determine whether charitable trusts are worth promoting and preserving.

Assuming arguendo that the wealthy would be equally generous in their charity regardless of their use of foundations, are there still valid reasons for promoting the creation of foundations? Do foundations provide benefits not present in other means of charity? The an-

${ }^{209}$ See Macey, supra note 193, at 303-04 (discussing the case of Evans v. Abney, 396 U.S. 435 (1970)).

${ }^{210}$ W.J. Hume, Preface to WOOSTER, supra note 26 , at vii. 
swer to both of these questions is a definitive "yes." The following are examples of the valuable attributes of foundations.

\section{a. The Transfer Function}

One commentator notes that the primary function of foundations is to act as a transfer mechanism. ${ }^{211}$ Foundations take in money from the upper class and distribute those funds to reputable nonprofit organizations. The claim is that foundational support has been vital to the stability and well-being of these organizations. ${ }^{212}$ Skeptics might contend that the wealthy would support charitable organizations regardless of their use of foundations, and that foundations are merely middlemen creating increased administrative costs. ${ }^{213}$ Nonetheless, supporters of foundations note that "it is not easy for a person of great wealth to personally dispose of large amounts of money intelligently and wisely. Efficient generosity requires an organization and expert assistance." ${ }^{214}$

Through a foundation, a donor effectively hires professional managers-trustees-who are asked to recognize the donor's wishes and to ensure that her wealth is distributed according to those wishes in perpetuity. The trustees serve as the donor's eyes and ears long after she has passed. The donor sees the foundation as a viable mechanism for transferring her funds according to her philosophy, regardless of whether that donor is personally able to oversee her charity. The foundation works as a transfer device because it fosters donor trust.

\section{b. Voluntarism and Capitalism}

Foundations preserve two traditions Americans cherish: voluntarism and capitalism. ${ }^{215}$ They allow people to contribute to the public welfare independent of government mandates such as taxation. Ad-

211 See WALDEMAR A. NIELSEN, THE Big Foundations 400-05 (1972) (noting that foundations provide measurable financial sustenance to charitable organizations that ensures the stability of the system).

${ }^{212}$ See id. at 400 ("Foundations are thus an integral part of the present American institutional establishment. By their contributions they help primarily to ensure the stability and continuity of the system.").

${ }^{213}$ See id. at 403-05 (questioning the need for foundations in light of their costs, which include administrative expenses and damage to public confidence in the national tax system because of special tax privileges to the very rich).

${ }^{214}$ FISCH ET AL., supra note $3, \S 42$, at 42 .

213 See NIELSEN, supra note 211 , at 401 . 
ditionally, the value of charitable trusts is heavily influenced by the belief in the free market and self-determination. The American creed stands for the view that people are allowed to accumulate vast quantities of wealth and dispose of it in the way they see fit (as long as neither is done illegally or tortiously). ${ }^{216}$

\section{c. The Foundation as a Creative and Expressive Tool}

Because the foundation is easy to create and operate, it allows individuals to maintain their own charitable projects. In this sense, a foundation is a tool for creativity in giving. It allows a person to commit funds to programs that express that individual's personalized set of values. ${ }^{217}$ Therefore, the foundational system can fund projects that might not find governmental or mainstream societal support. ${ }^{218}$

Foundations can perpetuate the visions and philosophies of their donors. Because the donors of charitable trusts tend to be successful people, ${ }^{219}$ the preservation of their creativity and foresight is logically a valuable resource for future generations. A foundation can preserve the unique ideology of the donor that proved prudent and successful during the life of that donor, and that also has the potential to produce successful results after the life of that donor. ${ }^{220}$

The arguments set forth in this Part have demonstrated the value of foundations. Recognizing the value of the foundation as a charitable instrument substantiates the claim that donor intent is worth protecting. Therefore, the law should guard against neglect of donative intent in charitable trusts in order to preserve the future of foundations.

${ }^{216}$ See id. (noting that private philanthropy sprang from the "interrelatedness of private property, religious and ethical values, and democracy" (citing JOSEPH A. SCHUMPETER, CAPITALISM, SOCIALISM, AND DEMOCRACY (3d ed. 1950))).

${ }^{217}$ See FISCH ET AL., supra note $3, \S 42$, at 42 n.57 (" [T] he foundation has a special potential for the development and expression of original ideas, for the harnessing of individual creativity." (citation omitted)).

${ }^{218}$ For example, the Hewlett Foundation of California, a foundation with hundreds of millions in assets, provides grants for research on population control and fertility reduction. See NIELSEN, supra note 150, at 207, 211. The Barnes Foundation is another example of unique charitable funding.

${ }^{219}$ See Eugene Steuerle, Charitable Giving Patterns of the Wealthy, in AMERICA's WEALTHY, supra note 4 , at 203,215 (providing the findings of a study showing that the wealthiest people are those most likely to start new charities or foundations).

$=20$ As one man stated, "If you have got enough sense to make the money, you ought to have enough sense to give some direction as to what you are going to do with it.' Odendahl, supra note 22, at 230. 


\section{SUGGESTIONS FOR DONORS AND THE LEGAL SYSTEM TO AVOID THE PROBLEMS OF IMPROPER DEVIATION AND WAYWARD TRUSTEESHIP}

The goal in the preceding four Parts of this Comment was to set forth the proposition that disregard for donor intent is a problem encountered by many charitable foundations such as the Barnes Foundation, and to demonstrate that this problem needs to be addressed. The objective in this Part is to propose practical steps philanthropists and the legal system should take to inhibit the subordination of donor intent.

\section{A. Specificity and Priority}

In Ford, Carnegie and other similar situations, the philanthropists themselves must share in the responsibility for their foundations' failure to follow donor intent. These donors are at fault for providing very little instruction regarding the administration of their trusts. ${ }^{221}$ Donors often provide little guidance to their successors, naively assuming that those who control their charitable gifts will honor their philanthropic philosophies. ${ }^{222}$ Nevertheless, trustees accepting responsibility for the charity of another should follow in the traditions ${ }^{23}$ of the person who created the charity, even if that requires the trustees to investigate and uncover those traditions. The history of the Ford Foundation and Carnegie Corporation proves that trustees are occasionally unwilling to determine the intent of the trustor and sometimes even choose to ignore it. ${ }^{224}$

\section{Defining Charitable Purpose and Intent}

Donors of charitable trusts must be specific in developing the guidelines that control the purpose, use and administration of their foundations. ${ }^{225}$ If nothing else, the donor who wants her intentions followed should spell out her charitable philosophy, providing examples of acceptable and unacceptable uses for her foundation. If a donor has no preference regarding how her foundation should be ad-

221 See supra text accompanying notes 150 \& 155.

${ }_{222}^{2}$ See WOOSTER, supra note 26, at 124 (suggesting that donors should express their intentions as specifically as possible rather than leaving their fortunes to professionals who spend the money on causes they prefer).

${ }^{223}$ See NIELSEN, supra note 211 , at 320 (noting that trustees customarily honor the donors' notions about the priorities of the foundation).

${ }_{224}$ See, e.g., supra text accompanying notes 150-52 \& 156.

${ }^{223}$ See WOOSTER, supra note 26 , at 124. 
ministered, she should note her ambivalence in the trust instrument in order to avoid future conflict. Moreover, donors should clarify whether their charitable wishes are general in purpose or specificthus allowing for the proper application of the cy pres doctrine.

In the same manner, a donor who does not wish to manifest a general charitable intent must detail what circumstances constitute a failure of the specific purposes of her foundation. This donor should also establish how her trustees are to distribute her property or funds in the event of failure.

Unfortunately, the Barnes and Buck cases illustrate that specificity of intention is not a complete solution to the problem of donor intent. Although both donors were explicit, their trustees still attempted to deviate from the donors' specifications. As this Comment has documented, the Barnes trustees succeeded in their attempt, ${ }^{226}$ while the Buck trustees were thwarted in their attempt by a judge who was conscientious of the donor's wishes. ${ }^{227}$

\section{Expecting the Unexpected}

Donors must realize that their administrative schemes for giving will encounter obstacles due to economic, legal and social evolution. $^{228}$ The Barnes and Buck cases are paradigmatic examples of this problem. Recognizing this possibility, donors should provide for acceptable alternatives in the administrations and/or purposes of their foundations in the event of failure or dramatic change. ${ }^{22 y}$ A donor cannot be expected to foresee all of the circumstances that may occur, but she can leave instructions for common events.

Albert Barnes made an effort to follow this recommendation ${ }^{230}$ (although not thoroughly). Nonetheless, his wishes were ignored by his trustees. ${ }^{231}$ A donor should, therefore, explicitly prioritize the

${ }^{226}$ See supra Part I.B-C.

227 See supra Part III.B.

${ }_{228}^{28}$ See, e.g., In re Estate of Buck, No. 23259 (Cal. Super. Ct. 1986), reprinted in 21 U.S.F. L. REV. 691 (1987); In re Barnes Found., No. 58,788 (C.P. Ct. Montgomery County, Pa., Orphans' Ct. Div. July 21, 1992).

${ }_{229}$ See Sisson, supra note 94 , at 646 (noting that the trustor should include in the trust instrument instructions granting the trustee discretion in the event of certain triggering events).

See supra notes 73-75 and accompanying text (noting that Barnes specified that there were to be no amendments to the conditions of the Indenture after his death, and that in the case of failure, the trustees could disband the Foundation, giving away the collection to suitable institutions).

${ }^{291}$ See supra Part I.C (describing the wayward trusteeship of the Barnes Founda- 
guidelines of her trust. She should delineate which elements of her trust are most important and central to the purpose and administration of the foundation. If deviations are inevitable, trustees and courts will be better equipped to determine which deviations can be accepted without destroying the purpose of the trust and which deviations constitute a failure of the trust.

The suggestions mentioned thus far are self-help techniques that permit donors to influence the continuing purposes of their foundations. ${ }^{232}$ This Comment's final recommendation is directed at the legal system in its supervision of charitable-trust administration.

\section{B. Modifying the Legal Standard for Cy Pres and Deviation}

The Barnes case is a prime example of the legal system's failure to uphold donor intent in the face of charitable-foundation trustees who wish to deviate from that intent. Moreover, Parts I.C and II.C of this Comment highlight the difficulty in distinguishing between mere administrative deviation and deviation from purpose-the application of cy pres. As a result of these two problems, an additional legal hurdle should be erected to protect donor intent.

When courts are asked to rule on petitions of cy pres and/or deviation, their initial inquiry should focus on the necessity of the deviation. There should be a rebuttable presumption against permitting any type of deviation from the intent of the donor, which can be overcome only when the trustee makes a showing of indisputable need. ${ }^{233}$ Before courts undertake either traditional cy pres ${ }^{234}$ or administrative deviation ${ }^{235}$ analyses, they should pose two threshold questions to the parties seeking to deviate from the wishes of donors: (1) Have all reasonable efforts to comply with the terms of the Indenture been exhausted? $?^{236}$ and (2) Will the foundation fail in its purpose

tion).

For more suggestions, see WOOSTER, supra note 26, at 121-25 (advising, among other things, that donors create foundations with term limits since the longer a foundation exists, the greater the possibility that donor intent will be neglected).

${ }^{239}$ Some courts have already required a showing of need. See, e.g., Jacobs v. Bean, 108 A.2d 559, 561 (N.H. 1954) ("deviation is allowed ... only to the extent necessary to effectuate the primary purpose of the trust" (citing Citizens Nat'l Bank v. Morgan, 51 A.2d 841, 843 (N.H. 1947)).

${ }^{294}$ See supra Part II.B.

${ }^{295}$ See supra Part II.C.

${ }^{230}$ Exhaustion of all reasonable efforts would require a showing by the trustees that they pursued all avenues to remedy their foundation's problems that did not violate the wishes of the donor, and that these attempts proved fruitless. Thus, the only 
if the desired deviation is not allowed? ${ }^{237}$

The second question is, admittedly, very similar to the cy pres requirement that the particular purpose of the trust be impossible, impracticable or illegal, ${ }^{238}$ and is analogous to the deviation requirement that compliance with a particular trust term be impossible or illegal. ${ }^{239}$ Nevertheless, there are valid reasons for the inclusion of this threshold question. First, as failure of purpose only relates to impossibility or illegality, impracticality would not be sufficient grounds for moving beyond this threshold analysis. ${ }^{240}$ Second, this question is necessary to curtail the abusive use of administrative deviation; that is, the use of administrative deviation to achieve modifications that actually go to charitable purpose and cy pres, such as that evidenced by the Barnes

recourse available to the foundation requires some deviation (cy pres or administrative). Once the trustees satisfy their initial burden of demonstrating "exhaustion," the burden would shift to the party opposed to the requested deviation, requiring them to establish that nonviolative means are still available.

Because this test is fact specific, the best manner of demonstrating its application is through an example. In the Barnes case, the trustees never pursued aid from other charitable foundations or the government. Specifically, the trustees appeared to ignore offers from the Getty Trust to assist in their dilemma. See supra note 64 and accompanying text. Therefore, the trustees would be unable to prove that the desired deviations were necessary because they did not exhaust all reasonable efforts to comply with the Indenture.

${ }^{297}$ This second question examines what will happen to the foundation if the requested deviation is not granted. A failure-of-purpose test would require a showing that without the deviation, the foundation would simply not be able to operate in accordance with its specific or general intent. Therefore, there must be proof of impossibility or illegality of purpose under current conditions to satisfy the requirements of this test.

${ }^{238}$ See supra Part II.B. This threshold question, however, mandates a showing that the purpose of the trust will fail without deviation, whereas cy pres mandates a showing that the specific purposes of the trust have already failed. Thus, as applied to cy pres issues, the threshold question relates to the eventual failure of any determinable general charitable purpose.

${ }^{239}$ See supra Part II.C. Recall that administrative deviation requires a showing that the specific terms of a trust can no longer be followed, whereas the threshold question mandates a showing that the purpose of the trust will fail without deviation. This threshold question, as it relates to administrative deviation, will increase the level of scrutiny.

${ }^{240}$ See supra note 131 (discussing the Buck court's rejection of impracticality as proper grounds for the application of $c y$ pres). Impracticality should not be grounds for disregarding a donor's intent, because it is too ambiguous a standard. The use of impracticality allows courts and trustees to deviate from donor intent when they believe such deviation is convenient or suitable to their ulterior motives, such as efficiency. Because deviation should be reserved for cases of need, impracticality must be discarded as a standard. By excluding impracticality as a basis for surviving this second threshold question, only cases of impossibility or illegality will reach cy pres or administrative deviation analysis. 
case. ${ }^{241}$ Even when courts and trustees have the best interests of the donor's intent in mind, they are faced with the difficulty of determining what is central to the donor's intent and what is administrative. ${ }^{242}$ Requiring the initially high standard that failure of purpose, or potential failure, be a threshold element for either type of deviation removes some of the concern as to how a deviation is characterized.

If, and only if, the trustees can show that the answer to both of these threshold questions is "yes" should the court grant the trustees a hearing on the merits of $c y$ pres or administrative deviation. In undertaking traditional cy pres or administrative deviation analyses, courts should require that any deviations requested and permitted be as nondisruptive as possible to the terms of the indenture. ${ }^{243}$ This requirement addresses the central concern of this Comment-protecting donor intent.

Requiring that deviations be as minimal as possible would be consistent with the idea of desperate need as the basis for any modifications. As a practical matter, the degree of disruptiveness will be readily discernible if the donors follow the suggestions in Part V.A. That is, if a donor is explicit in articulating her purposes for a trust and prioritizing her concerns, her trustees and any courts hearing their petitions will have a better understanding of which deviations would be acceptable and which would be completely improper. If courts used the inquiry proposed here and if donors took the suggested precautionary steps, ${ }^{244}$ donative intent would be easier to identify and harder to disrupt.

\section{Responding to Possible Counterarguments}

\section{Trust Failures}

A foreseeable criticism of the threshold test proposed herein is that it will cause more trusts to fail. By increasing the level of scrutiny in the test that must be met before any deviations are allowed, many

${ }^{241}$ See supra Part II.C (noting how the Barnes court used administrative deviation to achieve improper modifications).

${ }^{242}$ See supra Part I.C (noting the trustees' and court's inability to distinguish between Barnes's central purpose and issues of administrative management).

${ }^{249}$ See Jacobs v. Bean, 108 A.2d 559, 562 (N.H. 1954) (noting that the deviation permitted by the court "is no more than is necessary to accomplish the primary objectives of the testator").

${ }^{244}$ See supra Part V.A. 
more foundations will fail. ${ }^{245}$ While courts following this Comment's suggestions in Part V.B, and the analysis of cy pres in Part II.B, may be more willing to allow a trust to fail than to allow improper deviation (as in cases in which there is no finding of general charitable intent or a mere finding of impracticality of purpose), failure would not become a more prevalent phenomenon if donors follow the suggestions in Part V.A. If donors provide contingency plans and alternative uses in the event that their specific intentions cannot be followed, foundations will not fail due to changing circumstances. They will instead be redirected. The careful donor will provide alternatives and/or will explicitly grant greater trustee discretion if conditions change.

\section{The Convergence of $C y$ Pres and Administrative Deviation}

Critics of the threshold analysis may argue that it will lead to the merger of cy pres and deviation into one doctrine. Some people would consider this problematic, arguing that administrative deviation is by definition a lesser alteration, and therefore should be held to a lower standard of review. Moreover, critics might argue that such a convergence would be problematic because administrative deviation is a doctrine intended to promote the viability of specific donor intent, whereas cy pres is intended to sustain the general intent of the donor.

The threshold test would lead to some convergence of these two doctrines. This convergence, however, appears necessary in light of the historic applications of the two doctrines. Too often, there is confusion as to which doctrine is applicable to a specific case. Too often, one doctrine is used to further the agenda of trustees or courts, when the other doctrine is actually appropriate. This move toward convergence is a solution to these problems. By holding all deviation to the same initial standard, the law will minimize the effects of using one doctrine in place of another. This convergence is a recognition of the difficulties inherent in distinguishing between the elements of a donor's wishes that are merely administrative and the donor's actual purpose.

\section{CONCLUSION}

The preservation of donor intent in charitable foundations depends not on donors or the legal system, but on trustees. A donor

${ }^{245}$ For further discussion of trust failure, see supra Part II.B. 
can only monitor her trustees while she is alive. The legal system can only enforce donor intent when there is governmental interest in bringing the matter to court. ${ }^{246}$ The burden falls on trustees to monitor themselves-to recognize that the only reason they are trustees of a charitable foundation is because someone else donated her wealth to the public welfare and designated them as legal guardians of that wealth. Waldemar Nielsen appropriately concluded:

In the long term, the legitimacy of the institution of private philanthropy rests on the principle of trusteeship. Legally, the board of trustees is the foundation.... It is to this group of private persons that the donor "entrusts" his endowment, to be managed in accordance with his wishes, and in whom society places its "trust" that the institution will be managed for the public benefit. ${ }^{24}$

${ }^{246}$ Generally, only the state attorney general has supervisory power over enforcement of a trust instrument. Moreover, the attorney general rarely exercises this right. See FISCH ET AL., supra note $3, \S 682$, at 525 . Donors, their heirs and the beneficiaries of trusts have very little power to enforce or intervene in the enforcement of charitable foundations. See id. $\$ 717$, at 559-60. The issue of standing to enforce donor intent is a key one, but that is a topic for another Comment.

${ }^{247}$ NIELSEN, supra note 150, at 313-14. 
